Article

\title{
Comparing the Landscape Fragmentation and Accessibility of Green Spaces in Territories-in-Between across Europe
}

\author{
Alexander Wandl \\ Department of Urbanism, Delft University of Technology, 2600 AA Delft, The Netherlands; E-Mail: a.wandl@tudelft.nl
}

Submitted: 5 August 2017 | Accepted: 20 December 2017 | Published: 29 December 2017

\begin{abstract}
To improve the positive effects provided by green spaces on human well-being in dispersed urban areas is a key challenge for sustainable spatial development in Europe. This article presents a methodology that allows for the comparison of the potential of green spaces in Territories-in-Between across Europe, in a way that crosses the fields of urban ecology and urbanism. The article adds to the existing knowledge and understanding of the relation between the spatial organisation of systems of green spaces and their accessibility to biodiversity and human well-being. Firstly, it adapts the fragmentation index in a way that it can be applied to the specific spatial characteristics of Territories-in-Between. Secondly, it combines the fragmentation index with an indicator for accessibility of green spaces, in order to integrate aspects of ecology, human well-being and the spatial heterogeneity of the relation between them. The methodology is applied to ten areas across western Europe in order to inform decision and policy makers including urban planners, designers and environmental agencies to be able to assess the potential of system of green spaces for biological diversity and human well-being in an integrated manner.
\end{abstract}

\section{Keywords}

accessibility of green spaces; dispersed urban development; ecosystem services; landscape fragmentation

\section{Issue}

This article is part of the issue "Garden Cities and the Suburban Antidotes", edited by Markus Hesse and Geoffrey Caruso (University of Luxembourg, Luxembourg).

(C) 2017 by the author; licensee Cogitatio (Lisbon, Portugal). This article is licensed under a Creative Commons Attribution 4.0 International License (CC BY).

\section{Introduction}

The quality of urbanisation and related urban growth of cities are key challenges in securing and improving human well-being, as well as protecting and establishing ecosystems and their biodiversity. The reasons that cities play a crucial role in the relationship between well-being and biodiversity are, according to Pickett et al. (2008), (i) most of the planet's population lives in cities and therefore, human contact with nature is predominantly urban; and (ii) cities have impacts on regional and global ecosystems such as 'climate, atmospheric chemistry and hydrological systems' (p. 140), which go beyond the borders of urbanised areas. An increasing amount of literature within the field of biodiversity studies acknowledges that urban ecosystem structures such as green belts, parks of all sizes, rivers and creeks, private gardens, some derelict areas and brownfields, play a crucial role in preserving the planet's biodiversity (Eigenbrod et al., 2011; Parker, 2015). But the biodiversity benefits are unevenly distributed spatially, which raises questions concerning environmental justice. The 'increase in urbanization will result in spatial shifts in both supplies of ecosystem services and the beneficiaries of those services' (Eigenbrod et al., 2011). Who has access to which green spaces is a question that will challenge urban planning and design in the coming decades.

As much of the urbanisation of the last decades took place outside of the dense city cores (Kasanko et al., 2006), and it can be expected that the process of development of the 'horizontal metropolis' (Viganò, Arnsperger, Barcelloni Corte, Cogato Lanza \& Cavalieri, 2017) will go on in the near future, it is crucial to look at this new form of 'diffused city' (Secchi in Viganò et al., 2017) to 
answer the above question of environmental and human well-being. Wandl, Nadin, Zonneveld and Rooij (2014) used the term Territories-in-Between (TiB) as an umbrella term to characterise and map dispersed urban development across Europe, in order to compare them without favouring the cultural notions that come with some of the concepts. They include Zwischenstadt (D) (Sieverts, 2003), città diffusa (I) (Indovina, 1990), annaehernd perfekte peripherie ( $\mathrm{CH}$ ) (Campi, Bucher, \& Zardini, 2000), peri-urbanité (F) (Le Jeannic \& Vidalenc, 1997).

Urban areas are not homogeneous territories but have significant spatial differences in their demographic, physical and ecological structures. Metropolitan areas could be described in the words of Neutelings (1994) as a Patchwork Metropolis. Or as Huhlmann \& Promski $(2007$, p. 7) put it, 'the sharp distinction between city and countryside has dissolved into an ecological and cultural continuum of a built structure between city and landscape'. Therefore, it is not a surprise that this new spatial structure 'where we live now' (Sieverts, 2008) as well as the societal challenges and transformations that are related to the ongoing revolution towards the 'Industry 4.0' (Hermann, Pentek, \& Otto, 2016), made scholars revisit (Wahler-Żak, 2017) a concept that was developed as an answer to the challenges of the first industrial revolution: Howard's Garden City.

Already Howard stated that there are not only the two poles of urban and countryside, but that there is or could be a third pole, illustrated in his Town-Country magnet, that combines the beauty of the nature with the possibilities provided by economic and societal activities (Wahler-Żak, 2017, p. 19). Could it be that, in contrary to the many attempts of implementing the Garden City, which resulted in often green but mono-functional housing areas (Wahler-Żak, 2017), the 'diffuse city', which according to Secchi was not born out of the expansion of the city but 'had its roots in the territory, its inhabitants, and their history' (Secchi in Viganò et al., 2017), has the qualities listed under the Town-Country magnet?

The above description of diffused areas is very similar to the idea of the 'landscape mosaic', commonly used in landscape ecology (Dramstad, Olson, \& Forman, 1996), and is therefore a valid starting point for an integrated understanding of urbanised territories.

In order to inform decision and policy makers, including urban planners, designers and environmental agencies, it is crucial to be able to assess existing and proposed systems of green spaces in a way that integrates aspects of biological diversity and human well-being. Three aspects of TiB make them specifically relevant for the provision of ecosystem services: their sheer spatial size, the theoretical challenges in relation to the urban-rural dichotomy and the ongoing discussion of densification versus decentralisation.

We first describe the effects that are provided by ecological structures for both aspects: human well-being and preservation of biodiversity in TiB. Afterwards, we introduce two indicators, landscape fragmentation and accessibility of green spaces and adapt their calculation to fit the assessment of TiB. We use these indicators to compare the landscape fragmentation of $\mathrm{TiB}$ and the accessibility of green spaces in ten areas across Europe. We finish with a discussion of the advantages and limitations of the methods presented in this article.

The article adds to the existing knowledge and understanding of the relation between biodiversity and human well-being in two aspects. First, it adapts the fragmentation index (Jaeger, 2002) in a way that can be applied to the specific spatial characteristics of TiB. Second it combines the fragmentation index with an indicator for accessibility of green spaces, in order to integrate aspects of ecology, human well-being and the spatial heterogeneity of the relation between them. With these adapted methods we then test whether the hypothesis that less fragmented green space systems provide better accessibility to green spaces can be supported or not. Furthermore, it allows to identify which settlement patterns, and therefore spatial planning approaches, combine both biodiversity and accessibility.

\section{Green Structures in TiB and Their Relation to Human Well-Being and Biodiversity}

The integration of urban ecology and urbanism into a comprehensive regional planning approach is still a challenge in daily practice. Scott et al. (2013) even describe the disintegration (Shucksmith, 2010) of planning as a key characteristic of Territories-in-Between. Green spaces in TiB will be in the focus of both problems and potential solutions for environmental and social issues in the coming decades. According to Lovell and Taylor, urban green spaces are the key spatial structure of urban ecosystem services and 'will have a critical role to play in conserving biodiversity, protecting water resources, improving microclimate, sequestering carbon, and even supplying a portion of the fresh food consumed by urban dwellers' (2013, p. 1447). Moreover, green spaces, in the sense of public and private open spaces with a permeable and at least partly vegetation covered surface, continue to have to meet simultaneously cultural and esthetical needs of residents, encouraging leisure activities, and educating people about nature.

Large un-fragmented areas are crucial for biodiversity and health of plant and animal populations. Fragmentation decreases biodiversity (Beninde, Veith, \& Hochkirch, 2015; Dramstad et al., 1996; Faeth \& Kane, 1978; Jaeger et al., 2008; Jaeger, Soukup, Madriñán, Schwick, \& Kienast, 2011; Kane, Connors, \& Galletti, 2014). Levels of fragmentation vary significantly in TiB, depending on the elements that fragment landscape, and thereby block species dispersion and human mobility. These fragmentation elements can be of human nature (e.g., highways or other infrastructures, buildings and densely build up areas), or natural elements (e.g., high mountains, seas and rivers). How fragmenting these elements are is of course species-dependent. The result- 
ing spatial structure-of the web of infrastructure, as well as other human and natural fragmentation elements in $\mathrm{TiB}$ - is a patchwork of patches with a variety of size.

Eco-corridors are particularly focused for species dispersion and genetic exchange. They are very often considered more crucial then stepping stones (Angold et al., 2006; Beninde et al., 2015; Dramstad et al., 1996; Marulli \& Mallarach, 2005). In TiB, eco-corridors are often established along infrastructures (train lines, highways) and rivers, the same infrastructures that are also acting as barriers. Another key indicator for biodiversity is the percentage of vegetation cover and vegetation diversity: less than $10 \%$ seems a critical value (Aronson et al., 2014; Beninde et al., 2015; Clauset et al., 2009). $\mathrm{TiB}$ are mosaics of grey and green open spaces with different percentage of vegetation cover. Significant parts of green spaces are private areas such as gardens and agricultural land. Furthermore, derelict areas and brownfields are also usual on TiB.

Having defined three key characteristics of the structure of green spaces (patch size, corridors and vegetation cover), we can now relate them to the contributions to human well-being. The provision of healthy and affordable food and the possibility to grow food for yourself is the first to consider. There is high potential in TiB for urban agriculture (subsistence) as well as local (organic) food production, because of the large amount of garden area and small public green spaces (Andersson et al., 2007; Gómez-Baggethun \& Barton, 2013; Lerner \& Eakin, 2011; Thompson, 2012). Whether this potential is used depends both on the accessibility of these areas and the possibility to facilitate local producer-customer contact. However, the risk of pollution because of specific functions (highways, heavy industry and similar), and therefore a negative influence on the quality of food, is high in TiB.

Micro climate regulation, another relevant positive effect of green spaces, is related to the capacity of evapotranspiration of vegetation. The amount of sealed surface is crucial to mitigate the urban heat island effect (van der Hoeven \& Wandl, 2013). TiB usually have a rather high amount of impervious areas, but are also often the location of industrial areas or large infrastructure, which contribute to the urban heat island. Shopping malls and their large parking lots are also hotspots. This aspect is crucial when discussing future densification of TiB.

Air quality regulation is also directly related to the intensity of vegetation cover. Leaves reduce particulate matter, ozone, sulphur dioxide, carbon monoxide, and many more pollutants, but pollen can also cause allergies. These effects are very often local and need to take place close to the source of pollution. The intermingling of infrastructure, green spaces and housing areas in TiB is predesignated for that.

Green spaces are important for the development of educational, aesthetic and cultural values as well as im- proving recreation and physical and mental health. Experiencing (urban) biodiversity is a key to halting the loss of global biodiversity because people are most likely to take action for biodiversity if they have direct contact with nature (Beumer \& Martens, 2014; Müller \& Werner, 2010). Urban green spaces can contribute to human interaction by providing the possibility for both social interaction as well as privacy needs. Natural landscape features contribute to the development of aesthetic preferences and thereby contribute to a sense of community. Private gardens are one of the key attractors for people to move towards the edges of the cities and into TiB. On the other hand, TiB lack traditional urban landmarks, whilst landscape features are often contributing to a sense of place and community (Campi et al., 2000).

Green spaces in TiB provide possibilities for physical exercise: staying in or close to green spaces reduces stress as well as the heart rate; trees contribute to the purification of water and air as well as to balancing temperature; all these aspects are related to health issues such as respiratory diseases, obesity, sedentary lifestyles, cardiac diseases as well as loneliness. As most green spaces in $\mathrm{TiB}$ are either private gardens or privately owned agricultural areas, the relevance for this aspect is accessibility. Who has access with what means to which green spaces is crucial. Unclear ownership and responsibility for spaces provide both difficulties and potentials for accessibility.

Having discussed the relationship between the spatial structure of green spaces in $\mathrm{TiB}$ and their positive effects on human well-being and biodiversity we are able to identify indicators to empirically determine their relationship in reality. To summarize the content of the above, patch size, together with landscape fragmentation by infrastructure leads to a specific mosaic of patches in an area, which is very often brought into relation with the quality of ecosystems and their richness of habitats and species (Jaeger, 2002; Jaeger et al., 2011; Park, 2015). It is also increasingly recognised that the mosaic of patches is related to human well-being (Di Giulio, Holderegger, \& Tobias, 2009; Girvetz, Thorne, Berry, \& Jaeger, 2008) particularly to cultural and recreational aspects (Matsuoka \& Kaplan, 2008) as well as physical and mental health (Pretty, Peacock, Sellens, \& Griffin, 2005). Who has access to which green space is not covered by the description of the green space structure alone. It is relevant to know who can reach and profit from the relevant green spaces, that is, who lives within the service area of the different green spaces.

Therefore, we describe two indicators: landscape fragmentation and accessibility of green spaces, and how they have to be adapted to be used for the comparison of TiB. We also present the used data for calculating the indicators in the following paragraphs. Beforehand, the ten cases of the comparison of $\mathrm{TiB}$ across Europe are introduced. 


\section{Cases, Methods and Data}

\subsection{Selecting Ten TiB Across Europe}

This article is part of a PhD project, which compares Territories-in-Between across Europe in order to understand how planning approaches and spatial performance are interrelated. The method to identify TiB and the selection of case studies was published earlier in Wandl et al. (2014). The following is a brief summary:

(1) The cases should be located in countries that are characterised by different planning traditions, and therefore represent different approach towards sustainable development of TiB.

(2) The areas should be big enough that they contain urban areas and TiB as well as rural areas as defined by Wandl et al. (2014).

(3) The key regional planning documents had to be available in a language spoken by the $\mathrm{PhD}$ candidate. This is the reason why only cases in Western, Central and South Europe are included.
(4) For the first aspect, we have used the traditions (or ideal types) of spatial planning introduced by the European Compendium of Spatial Planning (European Commission, 1997) and further developed by Nadin and Stead (2013). These ideal types can be assigned to individual countries within the $\mathrm{EU}$, although in reality the different countries blend aspects of more than one ideal type. For the second aspect, we needed to decide on an ideal territorial sample size that would allow us to carry the analysis soundly. When located at the edges of big metropolitan areas, such as île-de-France or the Randstad, squares with a side length of $50 \mathrm{~km}$ proved to be big enough to cover areas classified as urban, rural and TiB. For other spatial analyses, an additional $25 \mathrm{~km}$ buffer around the $50 \times 50 \mathrm{~km}$ square was included, in order to avoid flawed results at the edges of the squares.

Figure 1 shows the location and name of the ten cases across Europe. Table 1 presents the cases with their ideal type of planning as well as the area that is classified as $\mathrm{TiB}$ and the number and percentage of population living within TiB.

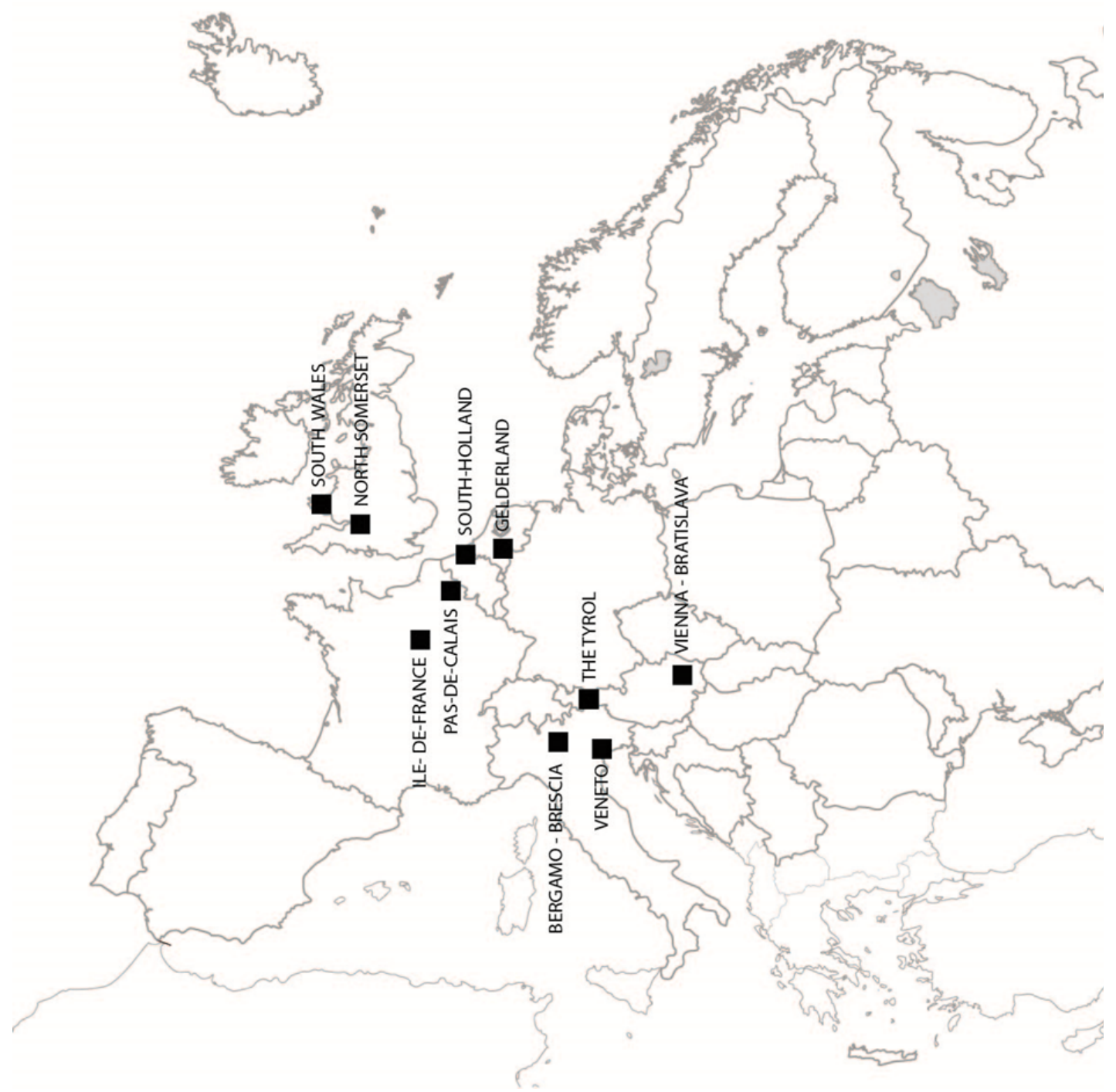

Figure 1. Name and location of the ten case studies. 
Table 1. Key features of the ten selected TiB across Europe for the year 2013.

\begin{tabular}{|c|c|c|c|c|c|c|}
\hline \multirow{3}{*}{ Case study name } & \multirow{3}{*}{ Ideal type of spatial planning } & \multicolumn{3}{|c|}{ Population } & & \\
\hline & & \multirow[t]{2}{*}{ Total } & \multicolumn{2}{|c|}{ in TiB } & \multicolumn{2}{|c|}{ Area classified as TiB } \\
\hline & & & & $\%$ & square $\mathrm{km}$ & $\%$ \\
\hline île-de-France & Regional economic & $3,893,228$ & $1,006,492$ & 25.85 & 1,096 & 54.16 \\
\hline South-Holland & Integrated comprehensive & $2,849,336$ & $1,267,325$ & 44.48 & 1,089 & 53.82 \\
\hline The Tyrol & Integrated comprehensive federal $^{1}$ & 281,199 & 203,066 & 72.21 & 379 & 18.73 \\
\hline North Somerset & Land use management & 736,265 & 562,595 & 76.41 & 790 & 39.03 \\
\hline Vienna-Bratislava & Integrated comprehensive federal & 338,470 & 266,489 & 78.73 & 735 & 36.34 \\
\hline Gelderland & Integrated comprehensive & $1,031,570$ & 832,782 & 80.73 & 1,083 & 53.51 \\
\hline Bergamo-Brescia & Urbanism & $1,094,195$ & 913,480 & 83.48 & 1,051 & 51.91 \\
\hline Veneto & Urbanism & $1,052,495$ & 888,305 & 84.40 & 1,299 & 64.16 \\
\hline South Wales & Land use management & 987,624 & 888,662 & 89.98 & 966 & 47.72 \\
\hline Pas-de-Calais & Regional economic & 970,905 & 913,379 & 94.08 & 1,205 & 59.53 \\
\hline
\end{tabular}

${ }^{1}$ Note that the for the Integrated Comprehensive Model 4, case studies were selected in order to be also able to compare the cases with strong national planning (NL) and the ones with strong federal planning (AT).

\subsection{Adapting Jaeger's Landscape Fragmentation Index for TiB}

The European Environment Agency (EEA) report Landscape Fragmentation in Europe (2011) provided the first assessment of landscape fragmentation for all EU countries using the following two indicators:

- effective mesh size $\left(m_{\text {eff }}\right)$;

- effective mesh density $\left(s_{\text {eff }}\right)$.

Both were introduced by Jaeger (2002) and further developed by Girvetz et al. (2008) and are an expression of the patch size of unfragmented areas. According to the EEA (2011, p. 17), 'the effective mesh size $\left(m_{\text {eff }}\right)$ serves to measure landscape connectivity, i.e. the degree to which movement between different parts of the landscape is possible. It expresses the probability that any two points chosen randomly in a region are connected; that is, not separated by barriers such as transport routes or builtup areas. The more barriers fragmenting the landscape, the lower the probability that the two points are connected, and the lower the effective mesh size. $m_{\text {eff }}$ can be expressed in the following formula:

$$
m_{\text {eff }}=\frac{1}{A_{t}} \sum_{i=1}^{n} A_{i}^{2}
$$

Where $n$ is the number of patches, $A_{i}$ to $A_{n}$ represent the patch sizes from patch 1 to patch $n$, and $A_{t}$ is the total area of the region investigated. The effective mesh density $\left(s_{\text {eff }}\right)$ gives the effective number of meshes per $\mathrm{km}^{2}$, in other words the density of the meshes. This number is very easy to calculate from the effective mesh size. It is simply a question of how many times the effective mesh size fits into an area (EEA, 2011, p. 24):

$$
s_{\text {eff }}=\frac{1}{m_{\text {eff }}}
$$

To calculate the landscape fragmentation a fragmentation geometry, which is formed by the built and natural elements that are impassable borders in a specific area, has to be defined. In Figure 2 we show a simple example how $m_{\text {eff }}$ changes with different fragmentation geometries.
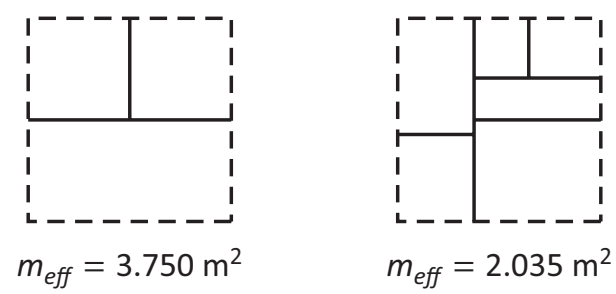

- - Area of interest Fragmentation geometry

Figure 2. Different fragmentation geometries and their effective mesh size. 
Jaeger et al. (2011, p. 28) use a combination of CORINE land use data, data of the street network, elevation data expressing high non-passable mountains, as well as temperature and river catchment areas to define their fragmentation geometry (see Table 2). They also state that it is important to reconsider and adapt the fragmenting elements for studies with different scope. The following paragraphs present such an adaptation for studying TiB on a regional scale.

For the comparison of TiB, the inclusion of discontinuous urban fabric into the fragmentation geometry seems problematic, as this area often includes low density built up areas with a lot of green spaces, mostly private gardens, which have a high percentage of vegetation cover and are crucial for certain benefits as mentioned earlier. Another problematic aspect is the complete exclusion of industrial areas, commercial units, roads and railroads, because the vegetated areas along these areas are very often ecological corridors, and also create buffer zones which provide benefits for human well-being such as purifying air and water and adding to aesthetical aspects of the landscape.

Therefore, the fragmentation geometry that was used to compare TiB across Europe was adapted. As Jaeger et al., we use the continuous urban land cover and the street network as a basis. But instead of using the other types of CORINE land cover, we used areas without vegetation cover as fragmentation elements.

To do so, the normalized difference vegetation index $(N D V I)$, which is an indicator for photosynthetic activity, was calculated. This was done using Landsat 5 images with $30 \mathrm{~m}$ resolution. This allows for the identification of landscape elements such as gardens or small areas of fallow land, which are often not blocking the dispersal of species, but are on the contrary, often important parts of an urban green network structure and exclude it from the fragmentation geometry.

The NDVI was acquired using the following equation:

$$
N D V I=\frac{I R-R}{I R+R} \times 100+100
$$

Where $R$ and $I R$ are the spectral reflectance in the TM red and near-infrared bands. The NDVI equation produces values in the range from $0-200$, where values bigger than hundred indicate vegetated areas and values smaller than 100 signify non-vegetated surface features. These values vary of course, reflecting different states of the vegetation process over the year. Therefore, cloudless images at the beginning of the Summer of 2009 were selected for the analyses and the final selection of the pixel values that were used as fragmentation geometry.

The year 2009 was used as it was the last period where for all cases cloud free image could be obtained during the vegetation period. Table 2 presents all datasets that were used to construct the fragmentation geometry.

\subsection{Accessibility of Green Spaces}

The key spatial elements that provide benefits for human well-being are green spaces, therefore the accessibility of green spaces can be seen as key indicator for human well-being in TiB. There are several standards that describe how much green space should be accessible to inhabitants of the area. Natural England, for example, defines the following (Comber, Brundson, \& Green, 2008, p. 104):

- No person should live more than $300 \mathrm{~m}$ from their nearest area of natural greenspace of at least 2 ha in size;

- There should be at least one accessible 20 ha site within $2 \mathrm{~km}$ from home;

- There should be one accessible 100 ha site within $5 \mathrm{~km}$;

- There should be one accessible 500 ha site within $10 \mathrm{~km}$.

Van Herzele and Wiedemann (2003), for example, propose a typology of green spaces and related sizes and distances of their service areas (see Table 3).

These approaches already demonstrate that there are quite some differences in the distances of service areas as well as sizes of green spaces. It is interesting also that none of the standards known to the author define precisely how to calculate these distances. Are those Euclidian, Manhattan or network distances? And from where to where is the distance measured, from access points of the green spaces or the centre of park?

According to Higgs, Fry and Langford (2012, p. 328) the identification of the following three elements has to be defined clearly in order to make a precise assessment:

1. an origin point, representing the geographical location of the population potentially seeking to access green space;

2. a destination point, representing the geographical location of the green space;

3. a distance measurement taken between these two points.

While we agree completely with points two and three, we would like to reconsider the first one. Defining an origin and destination matrix is a common approach for accessibility studies, but two aspects are critical. First, where should the point of origin within an analytical areal unit (municipality, census area or similar) be located? Second, the proposed method of point to point analysis does not allow drawing conclusions about which uninhabited areas have higher potential for future development, and therefore it has only limited value for planning. Therefore, we choose to use service areas, as these areas are within a specific network distance of a point of origin, instead of an origin to destination matrix. 
Table 2. Fragmentation elements according to Jaeger et al. (2011) in comparison to the adapted method.

\begin{tabular}{|c|c|c|c|c|}
\hline \multicolumn{2}{|c|}{ Jaeger et al. (2011) } & \multicolumn{2}{|l|}{ Proposed in this article } & \multirow[t]{2}{*}{ Comments } \\
\hline Data set & $\begin{array}{l}\text { Fragmentation } \\
\text { elements }\end{array}$ & Data set & $\begin{array}{l}\text { Fragmentation } \\
\text { elements }\end{array}$ & \\
\hline \multicolumn{5}{|l|}{ Landcover } \\
\hline \multirow[t]{6}{*}{$\begin{array}{l}\text { Corine Land } \\
\text { Cover (CLC) }\end{array}$} & $\begin{array}{l}\text { 1.1. Continuous } \\
\text { and discontinuous } \\
\text { urban fabric }\end{array}$ & \multirow{6}{*}{$\begin{array}{l}\text { Landsat 4-5 TM. } \\
\text { http://glovis.usgs.gov/ }\end{array}$} & \multirow{6}{*}{$\begin{array}{l}\text { NDVI: }>100 \text { and } \\
\text { Area }>200 m^{2}\end{array}$} & \\
\hline & $\begin{array}{l}\text { 1.2. Industrial, } \\
\text { commercial and } \\
\text { transport units }\end{array}$ & & & \\
\hline & $\begin{array}{l}\text { 1.3. Mine, dump and } \\
\text { construction sites }\end{array}$ & & & $\begin{array}{l}\text { Re-cultivated parts have a } \\
\text { NDVI }>100 \text { and are therefore } \\
\text { not considered as fragmenting }\end{array}$ \\
\hline & $\begin{array}{l}\text { 1.4. Artificial, } \\
\text { non-agricultural } \\
\text { vegetated areas }\end{array}$ & & & $\begin{array}{l}\text { Have a NDVI }>100 \text {; and form } \\
\text { part of the system of urban } \\
\text { green spaces, therefore not } \\
\text { fragmenting }\end{array}$ \\
\hline & 4.2.2. Salines & & & NDVI $<100$ \\
\hline & 5.1.2. Water bodies & & & \\
\hline \multicolumn{5}{|c|}{ Transport Infrastructure } \\
\hline \multirow[t]{7}{*}{$\begin{array}{l}\text { Tele Atlas } \\
\text { MultiNet } \complement\end{array}$} & $\begin{array}{l}\text { 00. Motorways ; } \\
\text { (Buffer } 30 \mathrm{~m} \text { ) } \\
\text { 01. Main Roads } \\
\text { (Buffer } 20 \mathrm{~m} \text { ) }\end{array}$ & \multirow{7}{*}{$\begin{array}{l}\text { Open Street Map } \\
\text { http://www. } \\
\text { openstreetmap.org/ }\end{array}$} & $\begin{array}{l}\text { Motorway; } \\
\text { Motorway Link } \\
\text { (Buffer } 50 \mathrm{~m} \text { ) }\end{array}$ & \multirow{7}{*}{$\begin{array}{l}\text { Buffers are wider, because } \\
\text { line features were used }\end{array}$} \\
\hline & $\begin{array}{l}\text { 02. Other Major Roads } \\
\text { (Buffer } 15 \mathrm{~m} \text { ) }\end{array}$ & & $\begin{array}{l}\text { Trunk; Trunk Link } \\
\text { (Buffer } 50 \mathrm{~m} \text { ) }\end{array}$ & \\
\hline & $\begin{array}{l}\text { 03. Secondary Roads } \\
\text { (Buffer } 10 \mathrm{~m} \text { ) }\end{array}$ & & $\begin{array}{l}\text { Primary; Primary } \\
\text { Link (Buffer } 24 \text { m) }\end{array}$ & \\
\hline & $\begin{array}{l}\text { 04. Local Connecting } \\
\text { Road (Buffer } 5 \mathrm{~m} \text { ) }\end{array}$ & & $\begin{array}{l}\text { Secondary; } \\
\text { Secondary Link } \\
\text { (Buffer } 24 \mathrm{~m} \text { ) }\end{array}$ & \\
\hline & Railroads (Buffer 4 m) & & $\begin{array}{l}\text { Tertiary; Tertiary } \\
\text { Link (Buffer } 10 \mathrm{~m} \text { ) }\end{array}$ & \\
\hline & & & $\begin{array}{l}\text { Light rail/Mono } \\
\text { rail (Buffer } 10 \text { m) }\end{array}$ & \\
\hline & & & Tram (Buffer 5 m) & \\
\hline
\end{tabular}

\section{Altitude, Slope and Temperature}

\begin{tabular}{|c|c|c|}
\hline WorldClim & $\begin{array}{l}\text { Mean temperature } \\
\text { July }<9.5 \text { Celsius }\end{array}$ & Not within TiB \\
\hline \multirow[t]{2}{*}{ Nordregio } & Elevation higher $2,500 \mathrm{~m}$ & Covered by NDVI $<100$ \\
\hline & $\begin{array}{l}\text { Elevation higher } 1,500 \mathrm{~m} \\
\text { and slope }>2 \text { degree }\end{array}$ & \\
\hline $\begin{array}{l}\text { CCM2: } \\
\text { Catchment } \\
\text { characterisation } \\
\text { and modelling } \\
\text { Version } 2.1\end{array}$ & $\begin{array}{l}\text { Catchment } \\
\text { areas greater } \\
\text { than } 3,000 \mathrm{~km}^{2}\end{array}$ & Not relevant for TiB \\
\hline
\end{tabular}


Table 3. Minimum standards for urban green spaces. Source: Van Herzele \& Wiedemann (2003, p. 113).

\begin{tabular}{lll}
\hline Functional level & Maximum distance from home & Minimum surface (ha) \\
\hline Residential green & 150 & 1 \\
\hline Neighbourhood green & 400 & 10 (park 5) \\
\hline Quarter green & 800 & 30 (park 10) \\
\hline District green & 1,600 & 60 \\
\hline City green & 3,200 & 300 \\
\hline Urban forest & 5,000 & 3
\end{tabular}

In order to assess the accessibility of green spaces three groups of sizes of green spaces were chosen:

- Green spaces between 1 and 10 ha, which are key for the provision of benefits for human well-being in the direct living surrounding, should be accessible in very short time and distance, and therefore also accessible for less mobile population groups like elderly and children;

- Green spaces between 10 and 30 ha, which serve bigger areas like districts in an urban environment, but also whole settlements in a more dispersed environment, with a bigger service area, but still used on a daily basis and should therefore be in a walking distance under 15 minutes (Matsuoka \& Kaplan, 2008);

- Green spaces larger than 30 ha, which have a regional effect.

In order to assess how many people have access to green spaces we assigned service areas to each of the classes of green spaces. A service area is the area from which any access point of a specific green space is reachable within a certain distance along the network of streets. As Table 4 shows, bigger green spaces have multiple service areas, as they provide in their closer vicinity the same services as smaller ones.

The calculation and mapping of the service areas requires the following steps.

- Selecting relevant green spaces-those un-fragmented areas (patches) that are bigger than 1 ha;

- Using the intersection points of the street network with the green spaces as access points to these green spaces. We applied a $25 \mathrm{~m}$ threshold for passing bystreets and paths to also consider that it's not necessary to actually enter the green space to profit from it;

- Calculation of the service areas along the street network, using the ARCGIS network analyst for the radii in Table 4, from each of the access points.

The service areas of the different green spaces may overlap and thereby create an intensity map of access to green spaces. This intensity map is than overlaid with a $1 \mathrm{~km}$ grid which contains the size of population. The resulting map and dataset shows then where and how many people have which intensity of access to green spaces.

\subsection{Combining the Two Indicators}

The aim of the article is to draw conclusions on both ecological qualities of the system of green spaces-as well as on the benefits for humans the system of green spaces provides-in a way that regional planners and designers can assess future plans and projects. Therefore, two methods of combining the indicators were chosen. The first one combines both indicators on a systems level. It is a simple juxtaposition of the effective mesh size of a case and the intensity of access to green spaces. Intensity stands for the amount of green spaces a specific part of the population has access to: the more green spaces, the higher the intensity. This allows to consider if less fragmented green networks also provide a higher intensity of accessibility to green spaces.

The second method presents the amount of green space according to the three categories of size in Table 4 and relates them to the percentage of population for whom they are accessible. This provides a better understanding about the relation of accessibility and the size distribution of the green spaces in a system and allows

Table 4. The different sizes of green spaces and their service areas.

\begin{tabular}{llll}
\hline Size of green space in ha & \multicolumn{3}{l}{ Service area distance in $\mathbf{m}$} \\
\hline $\mathbf{1}$ to $\mathbf{1 0}$ & 400 & 800 & 3,500 \\
\hline $\mathbf{1 0}$ to $\mathbf{3 0}$ & 400 & 800 & 300 \\
\hline $\mathbf{3 0}$ & 400 & & \\
\hline
\end{tabular}


us to reflect whether a green space system with a few large green spaces performs better than one that has a variety of sizes.

\section{Results}

This section presents firstly the advantages of the above described method of defining the fragmentation geometry based on NDVI, using the case of South-Holland as an example. Second, the resulting landscape fragmentation is presented for all cases, as well as the distribution of the different patch sizes of green spaces in the ten TiB. Thereafter, the results of the accessibility of green spaces study, following the early described method, are presented. Finally, two ways of combining both indicators are presented: the first compares both on the level of the system of green spaces, the second investigates how the different distribution of patch sizes is related to the accessibility.

\subsection{Refined Fragmentation Geometry Based on NDVI}

In the following we use the case South-Holland as a demonstration case to show the advantages of the methodology described above in representing the complex green structures in TiB. The following Figures 3 and 4 present the two steps of building the fragmentation geometry for the case of South-Holland.

Figure 5, which presents the comparison between fragmentation geometry using the datasets proposed by Jaeger et al. and our adapted method shows clearly the advantage of the latter. The large glasshouse areas south-

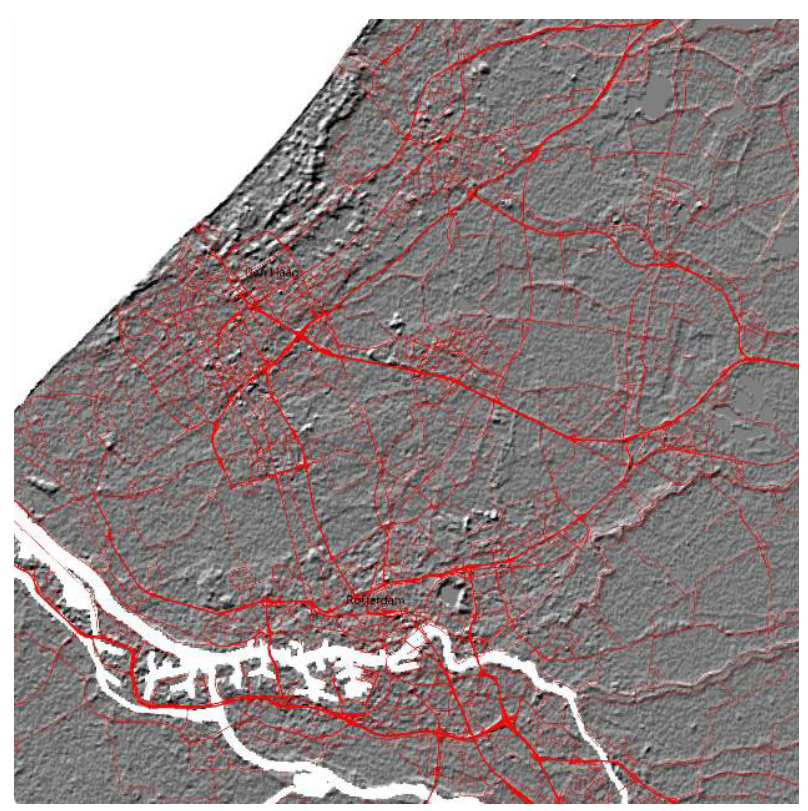

Figure 3. The first step of the fragmentation geometry (in red) based on street and railway network obtained from open street map data for the $50 \times 50 \mathrm{~km}$ square in the case of South-Holland. Source: author. west of The Hague for example, which fall in the CLC class non-irrigated arable land and do not, in the method of Jaeger et al., contribute to the fragmentation geometry, although they are completely built up areas and thus should be included in our fragmentation geometry. The green spaces at the edge of The Hague, which belong to the CLC discontinuous urban areas, are considered to be part of the fragmentation geometry according to Jaeger et al., although they play a crucial role as green corridor system of the The Hague-Rotterdam Metropolitan region. Our method identifies them as such and excludes them from the fragmentation geometry.

\subsection{Comparing Landscape Fragmentation in TiB across Europe}

Table 5 presents the effective mesh size as well as the mesh size density for the entire (urban, rural and TiB) case study areas as well as only for the TiB within the square of 50 by $50 \mathrm{~km}$. As expected, Table 5 and Figure 7 show that the two cases with the smallest population figures are the least fragmented and the one with the largest population density is the most fragmented. The ranking of the other cases does not show a relation to population density, which is an interesting outcome.

Before comparing the fragmentation only within $\mathrm{TiB}$, it is important to mention, that the cases are much less diverse considering the density of inhabitants, than for the whole case study area. Also, the ranking among the cases considering the population density changed. TiB in South-Holland are the most densely populated, followed by South Wales and Île-de-France (see Table 1). On

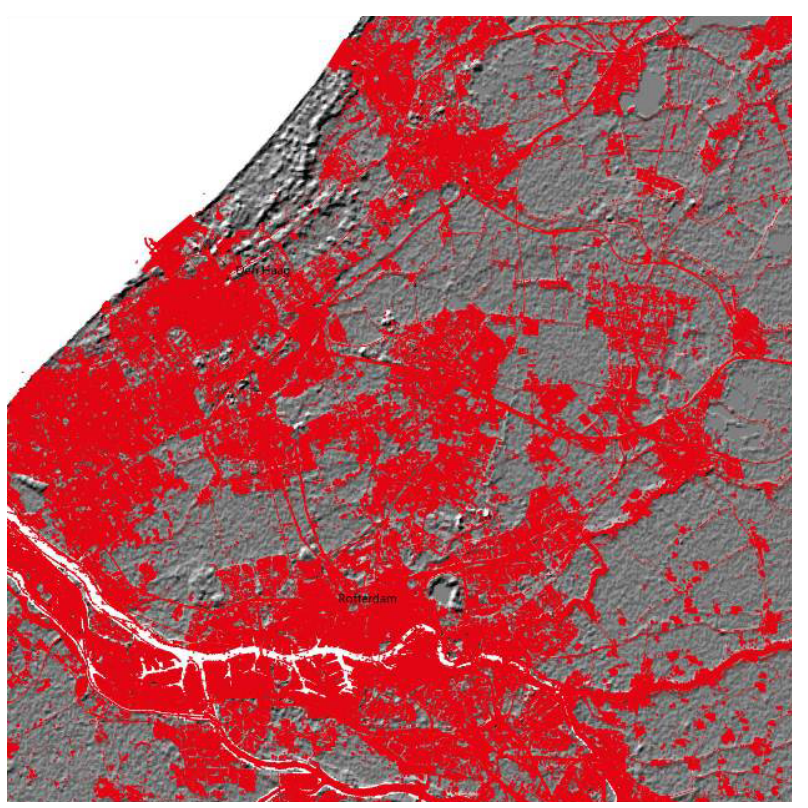

Figure 4. The complete fragmentation geometry (in red), including the areas which were selected through adding the results from the NDVI analyses. Source: author. 

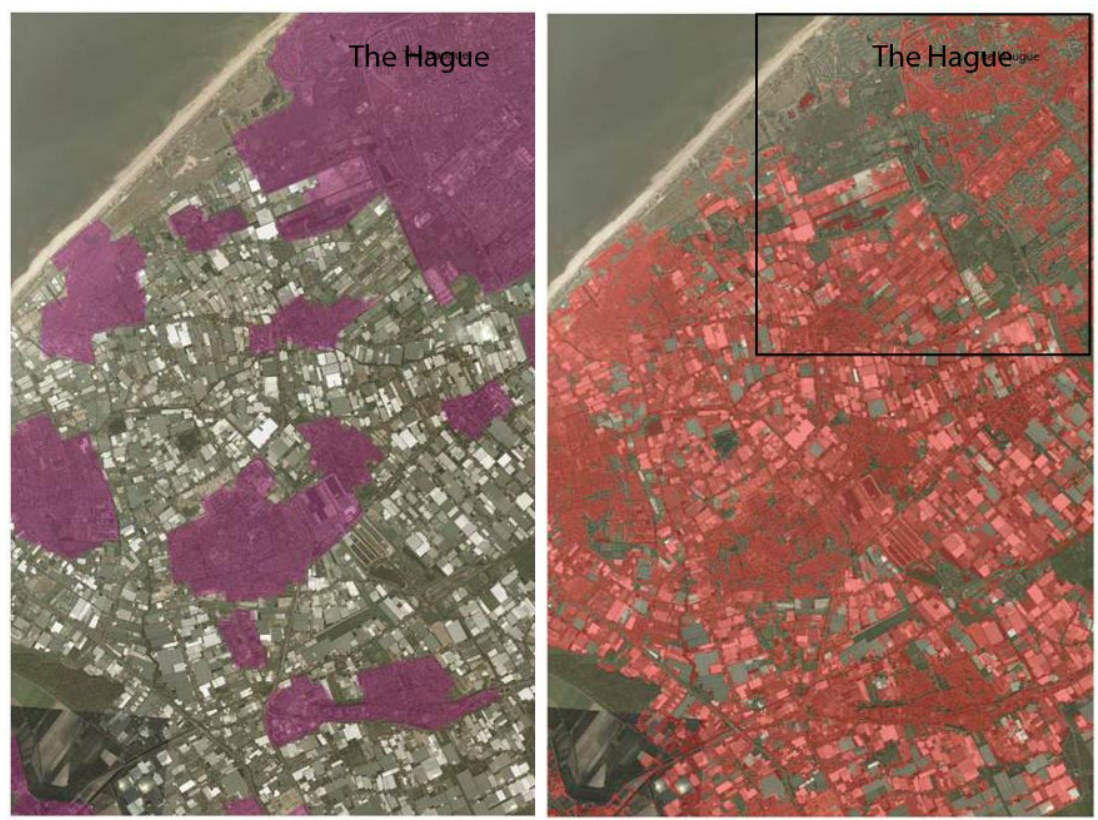

Fragmentation geometry based on CORINE landcover

Fragmentation geometry based on NDVI

Figure 5. The comparison of different ways of building the fragmentation geometry. On the right hand side using a NDVI based analyses and on the left hand side using CORINE land cover classes according to Jaeger et al. (2011). The black square shows the location of the bird's eye view of Figure 6.

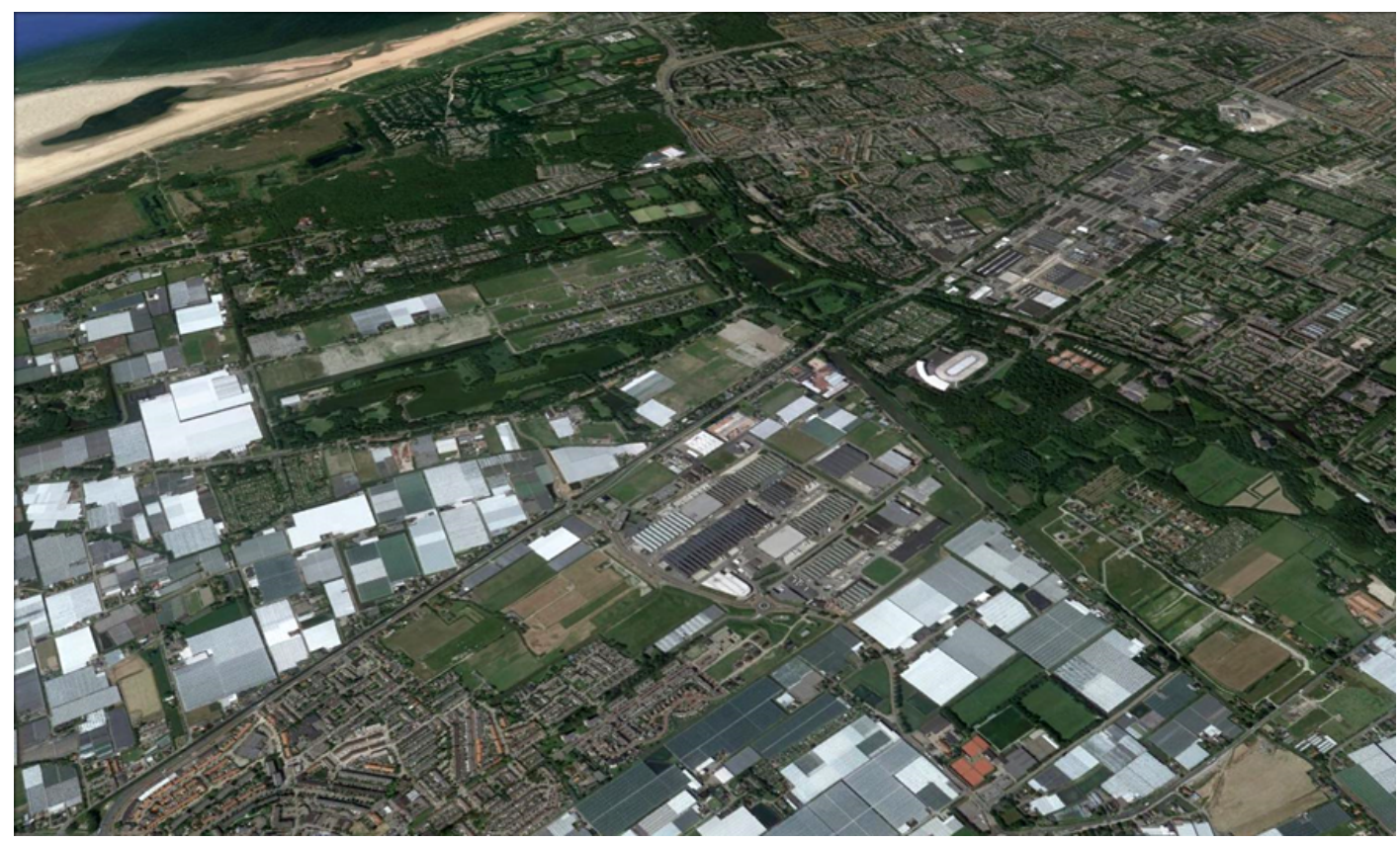

Figure 6. Bird's eye view over the TiB around The Hague showing the glass house areas on the left and the green buffer zone surrounding the suburban settlements. Source: Google Earth.

the less dense end of the list the Tyrol overtakes ViennaBratislava. The Veneto, which has the smallest difference between the overall population density and the population density in TiB, has the third least dense TiB.

The landscape fragmentation across the cases is much less diverse. The effective mesh size in the Tyrol is 220 times bigger than the one in île-de-France. This factor shrinks to four, when only comparing the effective mesh sizes of the TiB in those two cases. Considering only TiB, no relation between the population density and landscape fragmentation can be observed. The case with the lowest population density, Vienna-Bratislava, still performs best but the three most densely populated $\mathrm{TiB}$ are in the middle of the ranking. Therefore, it can be 
Table 5. Comparison of effective mesh size and mesh size density in the ten cases.

\begin{tabular}{|c|c|c|c|c|c|c|}
\hline \multirow[b]{2}{*}{ Case study name } & \multicolumn{3}{|c|}{ Total case study area } & \multicolumn{3}{|c|}{ TiB within case study area } \\
\hline & $m_{\text {eff }}$ & $S_{\text {eff }}$ & Rank & $m_{e f f}$ & $S_{\text {eff }}$ & Rank \\
\hline Bergamo-Brescia & 21.912 & 0.046 & 3 & 0.405 & 2.468 & 10 \\
\hline Gelderland & 9.191 & 0.109 & 8 & 0.956 & 1.046 & 7 \\
\hline Île-de-France & 0.875 & 1.142 & 10 & 1.485 & 0.673 & 4 \\
\hline North Somerset & 20.162 & 0.050 & 4 & 1.721 & 0.581 & 3 \\
\hline Pas-de-Calais & 9.694 & 0.103 & 7 & 2.303 & 0.434 & 2 \\
\hline South-Holland & 10.668 & 0.094 & 6 & 0.477 & 2.098 & 9 \\
\hline South Wales & 13.553 & 0.074 & 5 & 1.224 & 0.817 & 6 \\
\hline The Tyrol & 199.320 & 0.005 & 1 & 1.459 & 0.685 & 5 \\
\hline Veneto & 1.672 & 0.598 & 9 & 0.865 & 1.156 & 8 \\
\hline Vienna-Bratislava & 22.917 & 0.044 & 2 & 2.782 & 0.359 & 1 \\
\hline
\end{tabular}

concluded that natural topography, as well as elements like technical and green-blue infrastructures and the resulting settlement patterns and metropolitan structures, which are influenced by planning and design, have an influence on this indicator.

The overview of number and total size of green spaces per category, in Table 6, shows that in all cases but South-Holland, a few large (>30ha) green spaces count in total for more area of green spaces than all small and medium sized green spaces together. The accessibility of these large green spaces is therefore crucial when combining both indicators to understand the relation between the spatial structure of the system of green spaces and effects on human well-being.
Small green spaces account for more hectare than medium size green spaces in all cases. For the majority of cases, the smallest class of green spaces accounts for more than $97 \%$ of the number of green spaces. Exceptions are Pas-de-Calais and Gelderland, which count relatively more medium sized green spaces as well as large green spaces, namely around $3 \%$, compared to the mean of all cases, which is $1.9 \%$. Moreover, The Tyrol's share of medium (6\%) and large (10\%) green spaces is significantly different to all other cases.

Both Dutch cases have a significantly higher area of mid-sized green space. In contrast, the two Austrian cases have significantly less area that falls into this category. Within the TiB of Pas-de-Calais, The Tyrol and

Table 6. Comparison of the number and area of green spaces according to small, medium and large size, as well as the share of each in relation to the total number and area.

\begin{tabular}{|c|c|c|c|c|c|c|c|c|c|c|c|c|}
\hline \multirow[b]{2}{*}{ Case } & \multicolumn{4}{|c|}{ Green space $<10$ ha } & \multicolumn{4}{|c|}{$10 \mathrm{ha}<$ Green spaces $<30 \mathrm{ha}$} & \multicolumn{4}{|c|}{ Green spaces $>\mathbf{3 0}$ ha } \\
\hline & Nr. & $\begin{array}{c}\% \text { of } \\
\text { total } \\
\text { Nr. }\end{array}$ & $\begin{array}{c}\text { Area } \\
\text { in } \\
\text { ha }\end{array}$ & $\begin{array}{l}\% \text { of } \\
\text { total } \\
\text { area }\end{array}$ & Nr. & $\begin{array}{c}\% \text { of } \\
\text { total } \\
\mathrm{Nr} .\end{array}$ & $\begin{array}{l}\text { Area } \\
\text { in } \\
\text { ha }\end{array}$ & $\begin{array}{l}\% \text { of } \\
\text { total } \\
\text { area }\end{array}$ & Nr. & $\begin{array}{c}\% \text { of } \\
\text { total } \\
\mathrm{Nr} .\end{array}$ & $\begin{array}{c}\text { Area } \\
\text { in } \\
\text { ha }\end{array}$ & $\begin{array}{l}\% \text { of } \\
\text { total } \\
\text { area }\end{array}$ \\
\hline Bergamo-Brescia & 8,015 & 97.8 & 3,657 & 29.2 & 93 & 1.14 & 1,653 & 13.2 & 85 & 1.0 & 7,217 & 57.6 \\
\hline Pas-de-Calais & 5,260 & 93.7 & 3,101 & 11.9 & 158 & 2.81 & 2,746 & 10.5 & 198 & 3.5 & 20,213 & 77.6 \\
\hline île-de-France & 7,113 & 96.7 & 3,577 & 20.7 & 121 & 1.65 & 2,048 & 11.9 & 119 & 1.6 & 11,632 & 67.4 \\
\hline The Tyrol & 374 & 83.3 & 557 & 9.0 & 27 & 6.01 & 527 & 8.5 & 48 & 10.7 & 5,112 & 82.5 \\
\hline Gelderland & 4,169 & 94.0 & 2,135 & 13.6 & 127 & 2.86 & 2,372 & 15.1 & 140 & 3.2 & 11,199 & 71.3 \\
\hline North Somerset & 2,531 & 96.5 & 1,122 & 15.2 & 41 & 1.56 & 701 & 9.5 & 50 & 1.9 & 5,537 & 75.2 \\
\hline South-Holland & 9,789 & 97.9 & 4,598 & 36.0 & 134 & 1.34 & 2,300 & 18.0 & 81 & 0.8 & 5,883 & 46.0 \\
\hline South Wales & 6,296 & 96.6 & 2,737 & 19.7 & 117 & 1.80 & 1,947 & 14.0 & 102 & 1.6 & 9,213 & 66.3 \\
\hline Veneto & 7,210 & 96.0 & 3,719 & 19.3 & 145 & 1.93 & 2,700 & 14.0 & 154 & 2.1 & 12,826 & 66.6 \\
\hline Vienna-Bratislava & 2,921 & 97.1 & 1,295 & 12.8 & 28 & 0.93 & 455 & 4.5 & 58 & 1.9 & 8,406 & 82.8 \\
\hline
\end{tabular}


South Wales
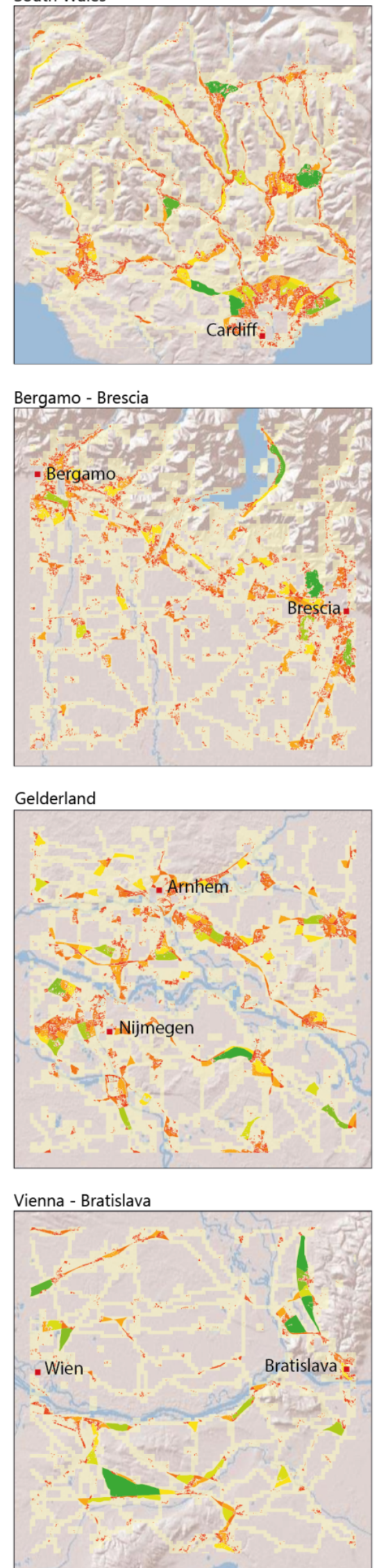

North Somerset
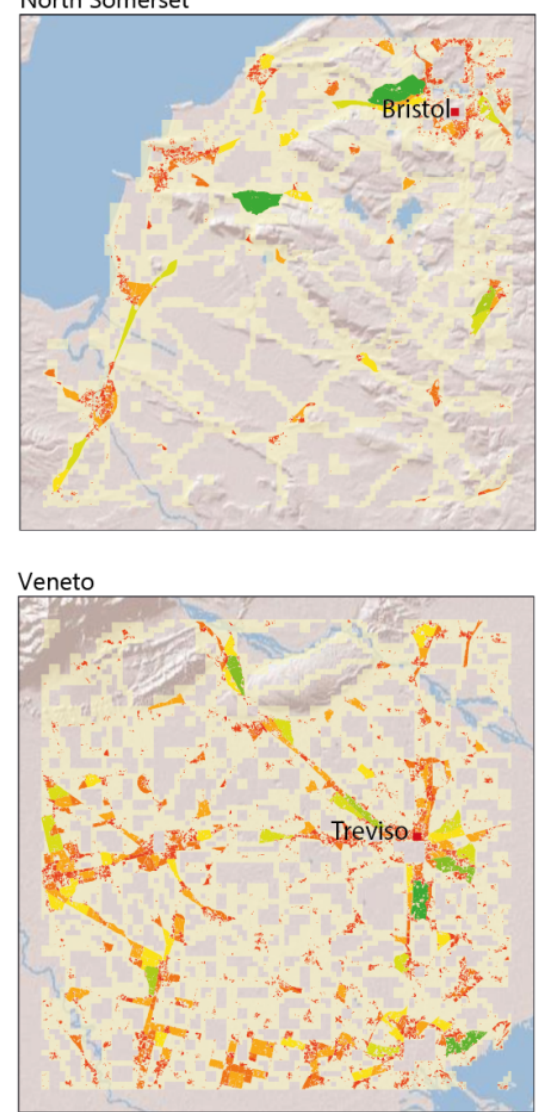

South-Holland
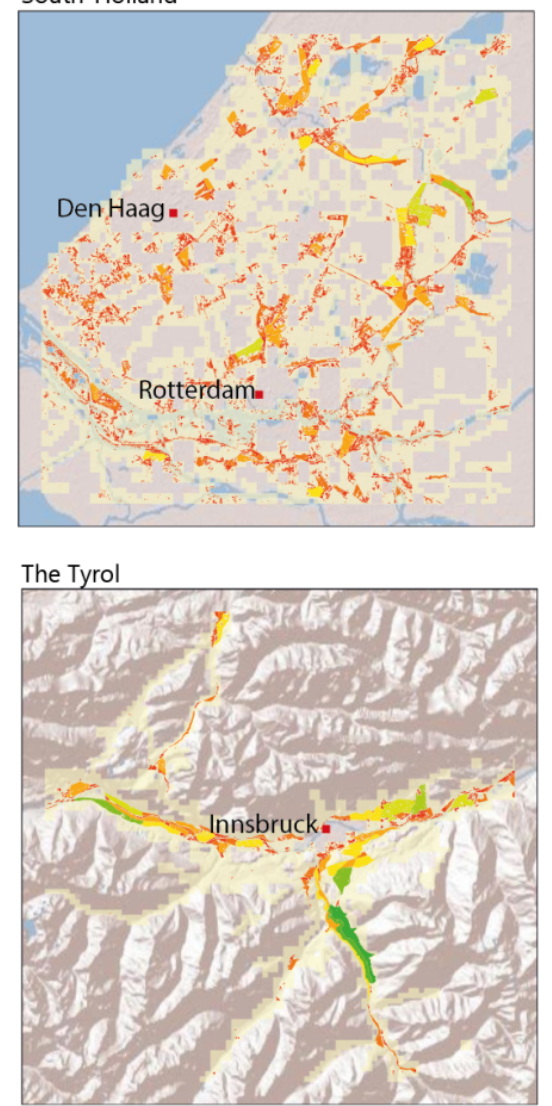
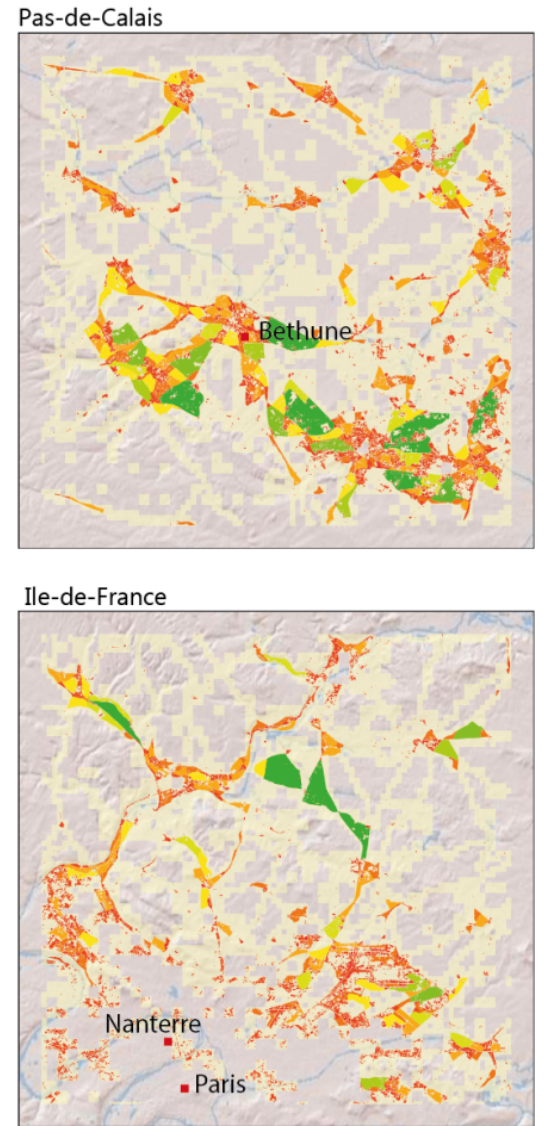

Effective mesh size and an effective mesh size density in Territories-in-between across Europe

\begin{tabular}{rccr} 
Case & mett & Sett & Rank \\
\hline Vienna - Bratislava & 2,781824366 & 0,359476325 & 1 \\
\hline Pas-de-Calais & 2,302852446 & 0,434244062 & 2 \\
\hline North Sommerset & 1,721393953 & 0,580924546 & 3 \\
\hline Ile deFrance & 1,485030502 & 0,673386842 & 4 \\
\hline The Tyrol & 1,459325953 & 0,685247869 & 5 \\
\hline South Wales & 1,223923943 & 0,817044233 & 6 \\
\hline Gelderland & 0,956168555 & 1,04584071 & 7 \\
\hline Veneto & 0,864781501 & 1,156361462 & 8 \\
\hline South Holland & 0,476711037 & 2,097706832 & 9 \\
\hline Bergamo - Brescia & 0,405123125 & 2,468385385 & 10 \\
\hline & & &
\end{tabular}

Comparing Landscape Fragmentation in Territories-in-between across Europe

Size of unfragmented area in $\mathrm{km}^{2}$

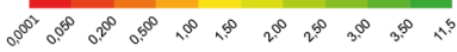

Territories-in-Between

Base map World Shaded Relief Copyright: 2013 Esri

$100 \mathrm{~km}^{2}$

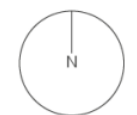

Figure 7. The landscape fragmentation of TiB in the ten case study areas. Source: author's own. 
Vienna-Bratislava are significantly more hectare of green spaces, which are classified as large green spaces compared to all other cases.

To summarize, if the hypothesis is correct that the amount of large green spaces is not only crucial for the landscape connectivity, but also for the accessibility of green spaces, then Vienna-Bratislava, The Tyrol and Pasde-Calais should perform best, and South-Holland should perform worst for the indicator accessibility of green spaces. If we follow the above argument that the effective mesh size is a better measure, also for the accessibility of green spaces, then Vienna-Bratislava, Pas-deCalais and North Somerset should perform best, whereas Bergamo-Brescia and South-Holland are expected to perform worst concerning the accessibility of green spaces.

\subsection{The Comparison of Accessibility of Green Spaces in the Territories-in-Between}

Before interpreting the data below, it is important to keep in mind that a minimum size of $200 \mathrm{~m}^{2}$ was chosen as lowest threshold to include a green space into the study. This means that isolated small green spaces, such as courtyards and small private gardens, are not considered. A general observation is that in all cases, except the île-deFrance, in both dense urban areas and TiB more than $50 \%$ of the population has access to at least one type of green space. For TiB this is true for all cases. Across all cases the percentage of population that has access to more than one type of green space is at least double the amount for $\mathrm{TiB}$ than for dense urban areas. The population within TiB that has access to at least one type of green space ranges from around 50\% (Bergamo-Brescia and Pas de Calais) to close to $90 \%$ in Gelderland. In the majority of cases (7 of 10) more than half the population of TiB has access to more than one type of green space. A comparison of the two metropolitan cases, the Île-de-France and South-
Holland, shows that the latter performs nearly twice as well. Cases from the same country perform rather similarly, again with the exception of France. The following Table 7 and Figure 8 present the number of people living in different zones of intensity of accessibility to green space in the different case study areas.

\subsection{Combining the Two Indicators and Interpreting Results}

In the following the two indicators are combined and interpreted in two different ways. The first combination, investigates, which category of size of green spaces serves the highest percentage of population. If the biggest green spaces serve the highest share of population, then the least fragmented TiB should be those with the highest accessibility of green space as well.

Figure 9 presents the percentages of population in TiB within the service areas of a specific size category of green spaces. Mind that percentages add up over $100 \%$, because certain parts of the population are served by more than one type of green space, which was expressed in the above described intensity of accessibility.

In all cases the largest category of green spaces serves the highest amount of population. In three cases The Tyrol, Gelderland and Pad-de-Calais, more than $80 \%$ of the population are served by large green spaces. In the Ile-de-France, as well as in Bergamo-Brescia, relatively few, below $50 \%$ of people are served by large green spaces. In the two Dutch cases relatively many people are served by medium sized green spaces. In the case of Vienna-Bratislava, the mid-sized green spaces only serve around $6 \%$ of the population and both Italian cases with around $11 \%$ also score rather low. South-Holland stands out with $27 \%$ of population served by small green spaces. The Veneto and the lle-de-France perform the weakest in this category.

Table 7. Intensity of accessibility to green spaces in urban areas and TiB in ten cases.

\begin{tabular}{|c|c|c|c|c|c|c|}
\hline \multirow[b]{2}{*}{ Case study name } & \multicolumn{3}{|c|}{ Urban areas in case study areas } & \multicolumn{3}{|c|}{ TiB within case study areas } \\
\hline & $\begin{array}{l}\text { Access to at least } \\
\text { one type (\%) }\end{array}$ & $\begin{array}{c}\text { Access to more } \\
\text { than one type (\%) }\end{array}$ & Rank & $\begin{array}{c}\text { Access to at least } \\
\text { one type (\%) }\end{array}$ & $\begin{array}{l}\text { Access to more } \\
\text { than one type (\%) }\end{array}$ & Rank \\
\hline Bergamo-Brescia & 47 & 7 & 9 & 53 & 24 & 10 \\
\hline Gelderland & 92 & 20 & 2 & 89 & 58 & 1 \\
\hline île-de-France & 11 & 1 & 10 & 52 & 28 & 9 \\
\hline North Somerset & 53 & 9 & 8 & 68 & 40 & 4 \\
\hline Pas-de-Calais & 96 & 35 & 1 & 83 & 52 & 3 \\
\hline South-Holland & 57 & 8 & 7 & 68 & 40 & 4 \\
\hline South Wales & 66 & 6 & 4 & 63 & 43 & 7 \\
\hline The Tyrol & 95 & 18 & 3 & 83 & 53 & 2 \\
\hline Veneto & 62 & 6 & 5 & 62 & 29 & 8 \\
\hline Vienna-Bratislava & 65 & 3 & 6 & 66 & 29 & 6 \\
\hline
\end{tabular}


South Wales

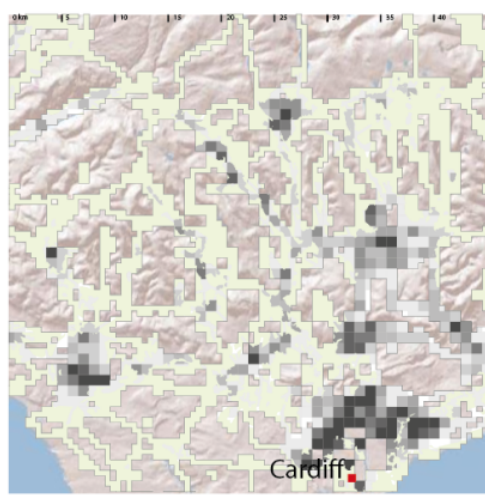

Bergamo - Brescia

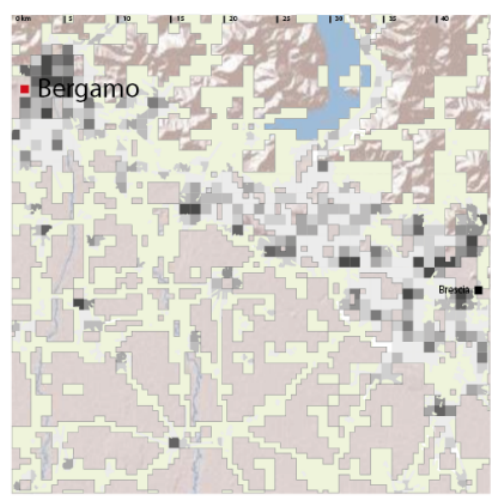

Gelderland

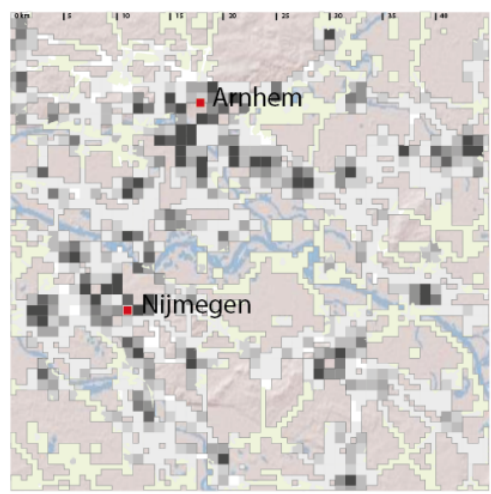

Vienna - Bratislava

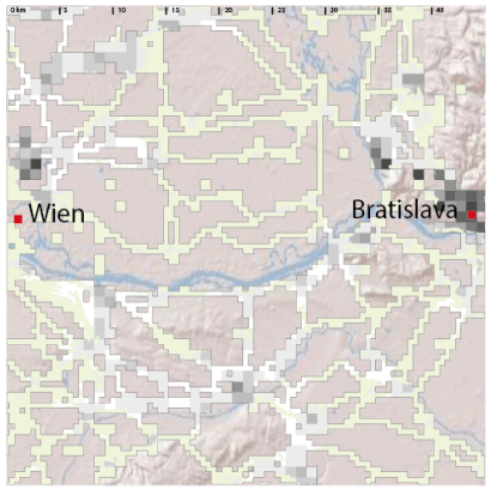

North Somerset

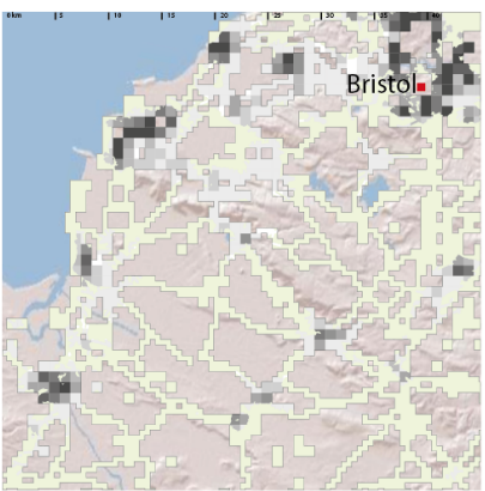

Veneto

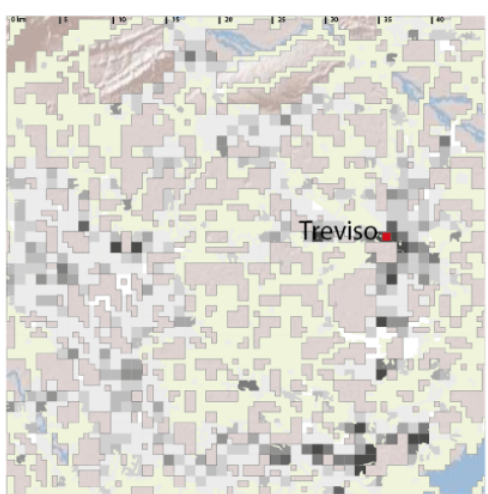

South-Holland

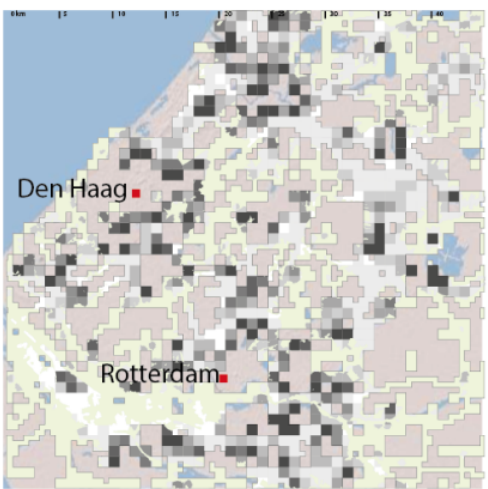

The Tyrol

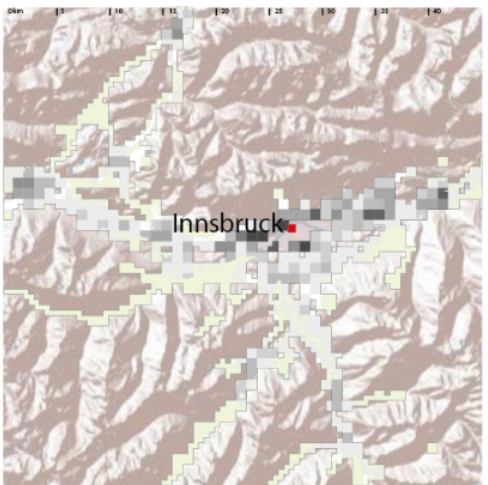

Pas-de-Calais

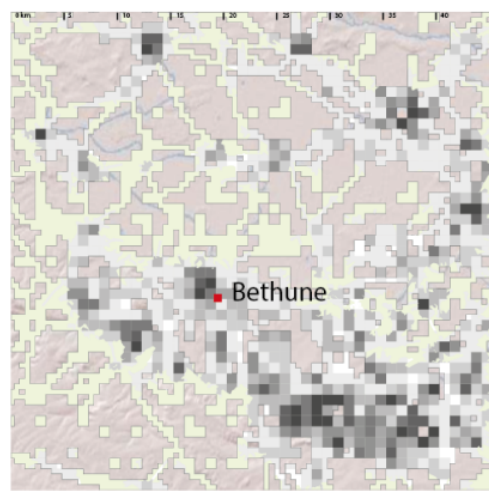

Ile-de-France

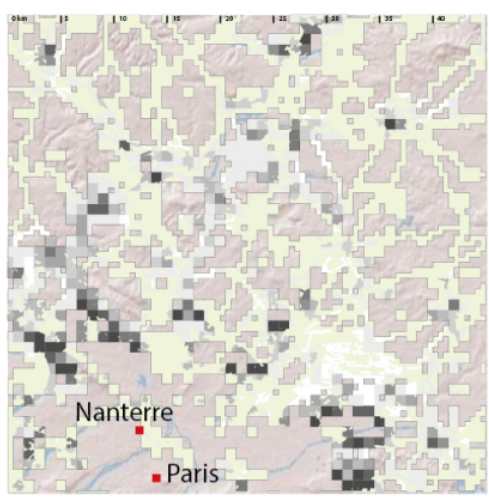

Comparing the accessibility of green spaces in Territories-in-between across Europe

\begin{tabular}{|c|c|c|c|}
\hline \multirow[b]{2}{*}{ Case study name } & \multicolumn{3}{|c|}{ Percentage of population with } \\
\hline & $\begin{array}{l}\text { access to at least } \\
\text { one type }\end{array}$ & $\begin{array}{l}\text { access to more } \\
\text { than one type }\end{array}$ & Rank \\
\hline Bergamo-Brescia & & & 10 \\
\hline Gelderland & 89 & 58 & 1 \\
\hline Mle-de-France & 52 & 28 & 9 \\
\hline North Somerset & 68 & 40 & 4 \\
\hline Pas-de-Calais & 83 & 52 & 3 \\
\hline South-Holland & 68 & 40 & 4 \\
\hline South Wales & 63 & 43 & 7 \\
\hline The Tyrol & 83 & 53 & 2 \\
\hline Veneto & 62 & 29 & 8 \\
\hline Vienna-Bratistava & 66 & 29 & 6 \\
\hline
\end{tabular}

Number of inhabitants per sq. $\mathrm{km}$ with access to green spaces within TiB
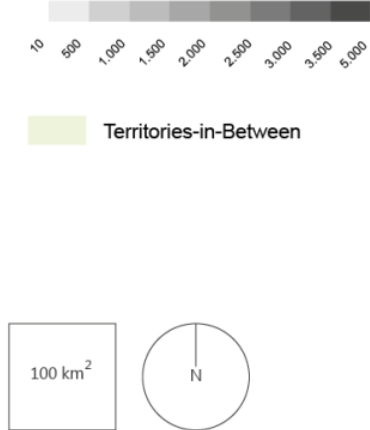

Figure 8. Comparison of accessibility across cases. 


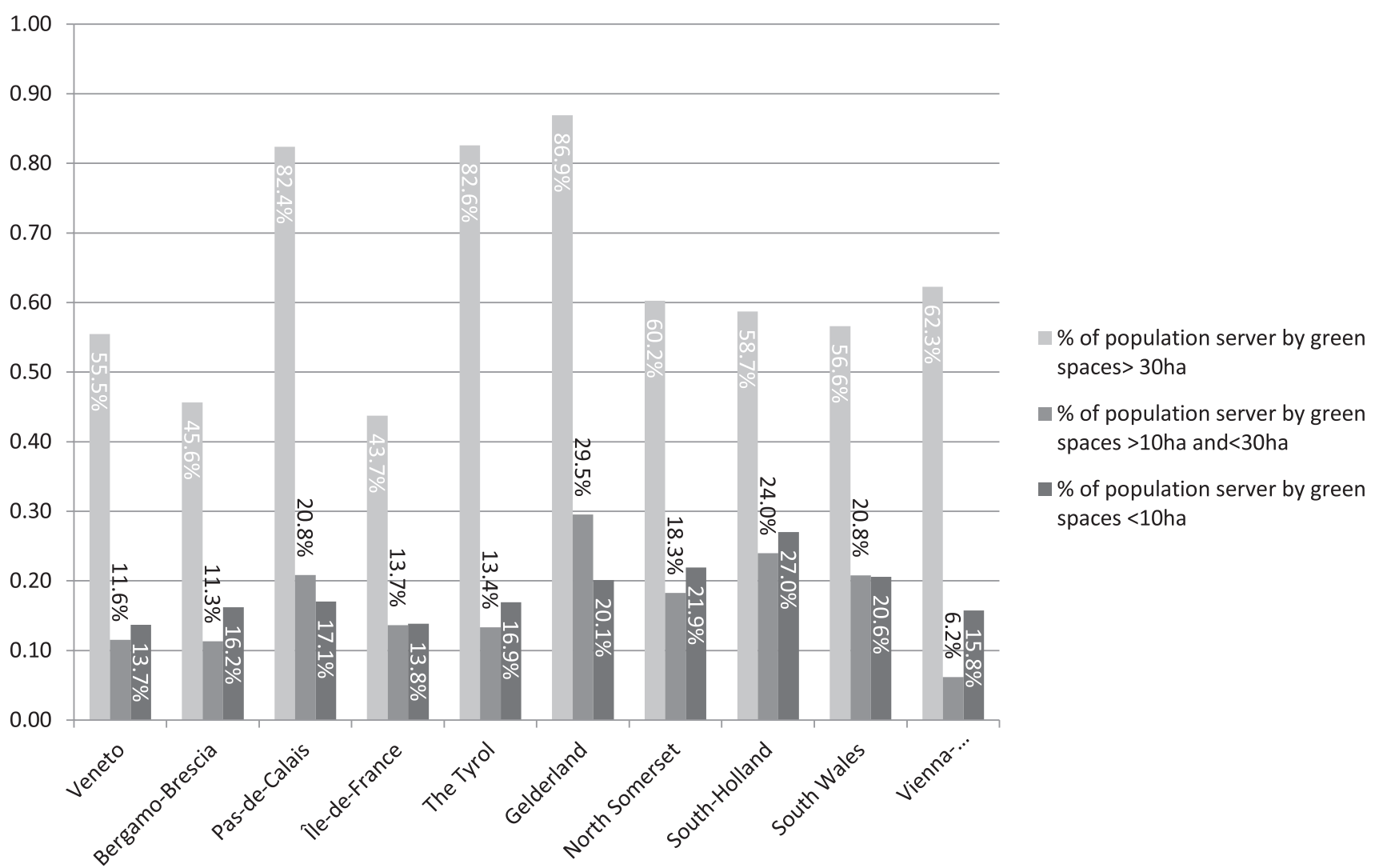

Figure 9. Population within the service area of specific sizes of green spaces.

Table 8 and Figure 10 present both indicators combined and show that there is not a clear relation between the performance of one indicator and the other. There are cases that perform relatively poorly (BergamoBrescia) or well (Pas-de-Calais) for both indicators, but there are also cases that perform relatively well for one and relatively poorly for the other (Gelderland). Therefore, an interpretation of the results needs always at least the combination of landscape morphological as- pects, economic development performance, as well as an understanding of the varying regional planning and design approaches.

Pas-De-Calais is the overall strongest performing case. This is the result of a settlement pattern that is characterised by rather compact towns and villages that are embedded in and separated from each other by an agricultural platform, which has rather small grainsize and a dense accessible network of agricultural paths. The

Table 8. Accessibility of green spaces as well as landscape fragmentation in TiB across Europe.

\begin{tabular}{lccccc}
\hline Case study name & \multicolumn{2}{c}{ Percentage of population with } & \multicolumn{3}{c}{ Landscape fragmentation } \\
\cline { 2 - 6 } & Access to at least one type & Access to more than one type & Rank & $\boldsymbol{m}_{\text {eff }}$ & Rank \\
\hline Bergamo-Brescia & 53 & 24 & 10 & 0.405 & 10 \\
\hline Gelderland & 89 & 58 & 1 & 0.956 & 7 \\
\hline Île-de-France & 52 & 28 & 9 & 1.485 & 4 \\
\hline North Somerset & 68 & 40 & 4 & 1.721 & 3 \\
\hline Pas-de-Calais & 83 & 52 & 3 & 2.303 & 2 \\
\hline South-Holland & 68 & 40 & 4 & 0.477 & 9 \\
\hline South Wales & 63 & 43 & 7 & 1.224 & 6 \\
\hline The Tyrol & 83 & 53 & 2 & 1.459 & 5 \\
\hline Veneto & 62 & 29 & 8 & 0.865 & 8 \\
\hline Vienna-Bratislava & 66 & 29 & 6 & 2.782 & 1 \\
\hline
\end{tabular}


South Wales
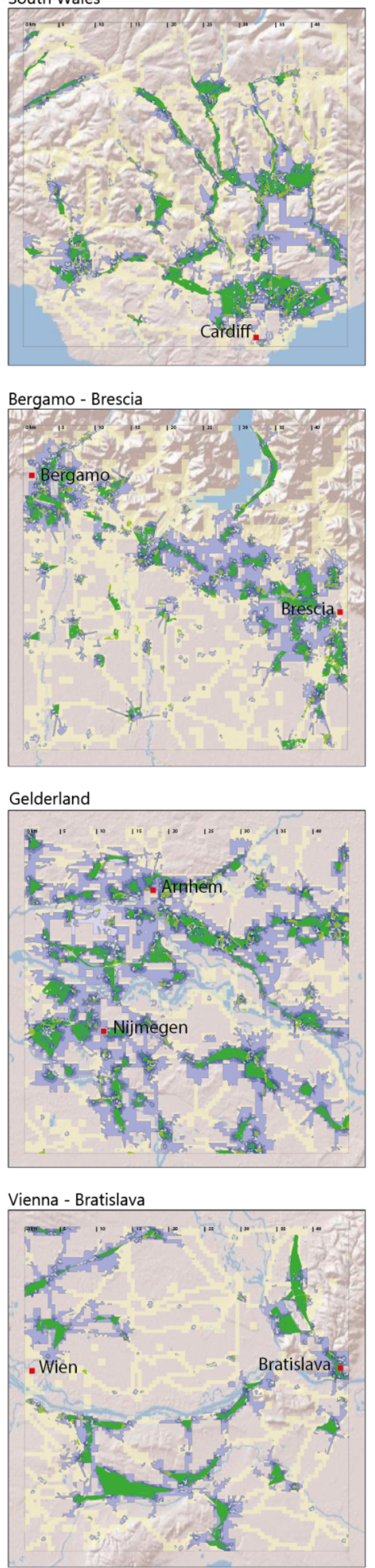

North Somerset
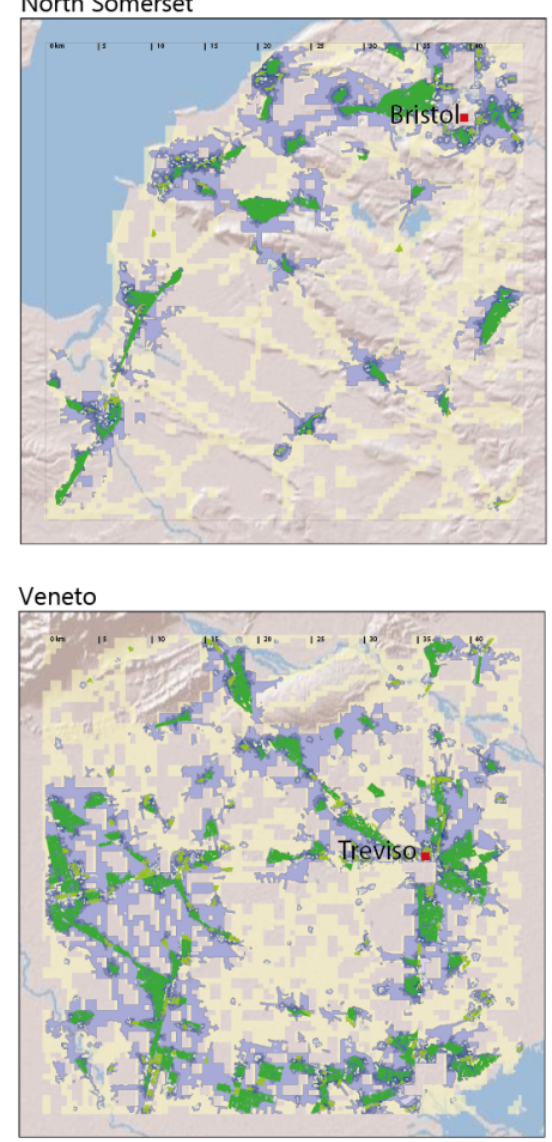

South-Holland
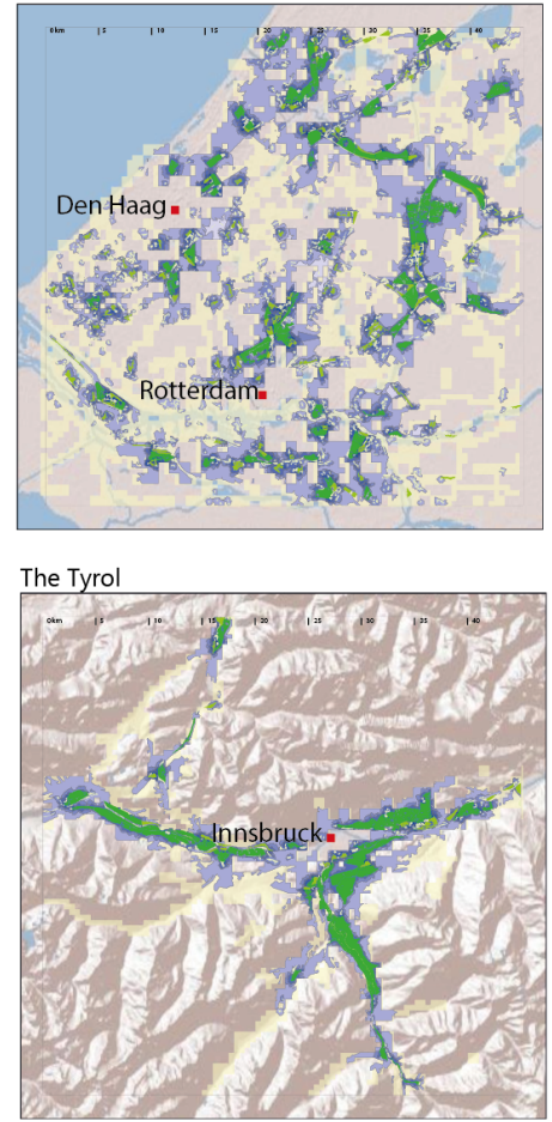

Pas-de-Calais
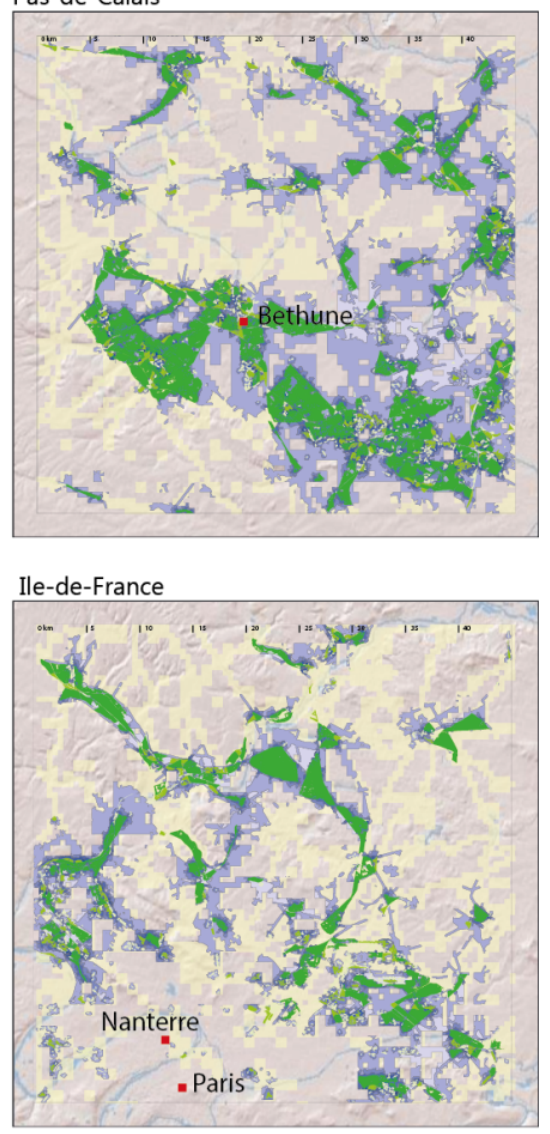

Intensity of Accessibility of Green Spaces

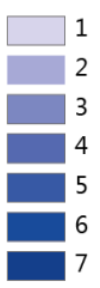

Size of Green Spaces in Hectare

$<10$
$>10$ and $<30$
$>30$

Territories-in-Between

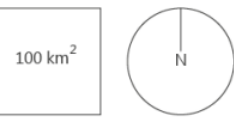

Figure 10. Overlay map of the combined indicators. 
compactness of the settlements is partly also the result of the economic decline of this former mining area during the last decades of the twentieth century. A network of green spaces that follows the rivers through towns and countryside functions as eco-corridors and increases the accessibility of green spaces. Finally, the ongoing transformation of mining brownfields into parks and leisure areas since the 1990s has contributed to the high performance of system of green spaces in the case of Pas-de-Calais.

Gelderland, which performs best for accessibility of green space but rather weak concerning landscape fragmentation, has also a compact settlement pattern with agricultural areas, which are highly accessible, specifically by bike, between each city or village. But the road network is much denser than in Pas-de-Calais and therefore, Gelderland shows a higher landscape fragmentation.

The second French case, which is situated at the northern border of the île-de-France, performs relatively well concerning the landscape fragmentation but relatively poor concerning the accessibility of green spaces. This result can be explained by the fact that most of the big green areas are large forests, mostly former feudal estates, which form large patches of un-fragmented areas and are also accessible by the public, but have rather few entrances, reducing their service areas. The enormous continuous settlement pattern of single family houses at the outskirts of Paris lacks a developed network of small and mid-sized green spaces. Here also rather large forests or parks are the dominant green spaces, which are again not accessible by many people within a short distance. Furthermore, business parks and infrastructure facilities are very often located at the edges of the settlements which may have curbing effects on future settlement development, whilst also blocking access to the agricultural platform and its ecosystem services.

A further interesting case is South-Holland. As one of the most densely populated cases it performs as expected, that is relatively poorly, concerning landscape fragmentation, and surprisingly relatively well concerning the accessibility of green spaces. The latter is the result of the ongoing protection of buffer zones between the cities, which are slowly developing into leisure areas, and the very dense network of regional bike paths that make this and other agriculturally used areas highly accessible. The extensive zone of dunes along the coast that are protected for their natural value and for flood defence reasons have only limited accessibility, but provide still benefits to big parts of the population. This coastal zone is, specifically in the post war areas of The Hague, connected to a well-developed network of green corridors and parks with many small and mid-sized green spaces.

The green belt around Cardiff and Newport, which forms the biggest part of the green space structure in the case of South-Wales, performs relatively and to a certain extent surprisingly weak, considering the idea of the green belt is one the originated from the garden city and should provide accessible countryside. The reason for the rather bad performances, is that the settlement pattern next to the green belt is a suburban cul-de-sac pattern, which means, low density and little possibility to walk through. Moreover, highways are fragmenting the green belt heavily.

The relative poor performance of the two Italian cases can be explained on the one hand by the dense infrastructure network in the areas, which leads to high landscape fragmentation, and on the other hand, the few large green areas. The green areas are often under natural protection and rather distant from larger settlements and not very well connected to them.

The Tyrol is a case where the influence of topography is very apparent. The fact that the TiB are all located within the valleys where also the infrastructure is concentrated, leads to a highly fragmented territory. However, the ribbon structure of the settlement pattern, has the consequence that big green spaces are very close to the settlements. This spatial configuration combined with a dense network of agricultural and touristic paths and streets - the result of a flourishing tourism industry of the last 50 years - provides a very high accessibility of green spaces.

\section{Conclusions}

We come back to the simple hypothesis set out: Do less fragmented greenspace systems in TiB provide also better accessibility to green spaces? And can we identify, which settlement patterns and therefore spatial planning approaches, combine both biodiversity and accessibility the best? The answer is, for the ten tested cases, that there is not a clear relationship between landscape fragmentation and accessibility of green spaces. There is the same amount of cases that perform equally weak/strong for both indicators, as there are cases that perform contrasting for both indicators.

Clear conclusions can be drawn for the settlement patterns that perform best. A large and un-fragmented regional network of greenspaces as backbone is crucial. Whether this is in the form of green belts, green fingers, buffer zones or landscape parks, does not make a big difference. Crucial is that these large green spaces are easily accessible, preferably by foot, bike or public transport. Furthermore, it is important that traffic and other infrastructures are located and designed in a way that they fragment the big green spaces as little as possible and do not block access to these large green spaces. It is also important to avoid cul-de-sac settlement patterns and gated communities, as well as impermeable industrial or business parks at the edge of the settlements.

Cases that have a more compact settlement pattern-where individual cities, towns and villages are separated by medium sized greenspaces-tend to perform better on both indicators. Crucial here is to make sure that the medium sized green spaces are easily accessible. In contrary to large green spaces, the midsized 
green spaces are often not part of national planning or environmental protection, therefore regional and cross municipal cooperating is essential to establish this part of a regional green system.

Finally, a large amount of fair distributed small green spaces is crucial as well. This is specifically relevant for $\mathrm{TiB}$, as ongoing densification is often related with a change of housing typology from single family housing with private gardens to flat buildings without private gardens. Moreover, densification transforms green spaces, which are often considered as underused, but are nevertheless essential for biodiversity and human well-being.

The presented results and maps have the potential to facilitate and inform discussion across the many fields of expertise and actors involved in protecting and assist in developing system of green spaces in TiB. This is specifically important for TiB, where the expected future densification of urban uses and the protection of (urban) biodiversity are causing and will continue to cause conflict among different groups of interest.

The above examples of the interpretation of the two indicators, with admittedly limited knowledge about the local specificities, provides an idea about their usefulness and limitations. The indicators, landscape fragmentation and accessibility to green spaces as well as their combination can be used to compare the potential benefits of green spaces on a regional or metropolitan scale, and thereby compare the performance of different settlement structures. The presented methodology allows for comparison of historic, present and proposed alternative future settlement patterns, and can inform regional planning and design as well as other policy fields.

The key advantage of the method described is the use of NDVI to identify green spaces instead of using CORINE land cover data, because remote sensing allows a more fine-grained identification of green spaces. Satellite data is readily available across the globe and allows, therefore, the methods to be applied worldwide. But there are also limitations as it is difficult to find satellite images, which have no cloud cover. Also, the time of the year the satellite image has been taken has an influence on the indicators. Only images during the vegetation period should be used and harvesting times of agricultural crops have to be considered otherwise barren land is not identified as green space.

A further limitation is that indicators express the potential effects of green spaces. As fieldwork shows, the actual access to specifically agriculturally used areas is often forbidden-this is specially true for the Italian cases. A similar aspect is that the method does not distinguish between private and public spaces, which means that private gardens are included in the assessment, not considering if they or the streets next to them are actually accessible or not. This is critical for gated communities with limited access and therefore, for aspects of spatial justice.

The last limitation leads to a crucial field of further research, which is to combine the indicators with addi- tional demographic data, (e.g., income, ethnicity or level of education), relating the accessibility of greenspaces and their positive human impacts more clearly to aspects of spatial justice. This kind of studies have been done for urban areas but not for TiB yet. The article also considers only the service areas of green spaces in relation to resident population, but it would be equally interesting and important to extend the assessment to the working population, as a large part of the population is not home throughout much of the day.

Finally, we can conclude that several of the qualities Howard formulated for his Town-Country magnet are present in TiB: beauty of nature and societal opportunity; fields and parks of easy access, pure air and water and good drainage. Those qualities are also related to the key benefits of green structures described in this article and shows how timeless Howard's vision is. It also shows that it is worth using both indicators in combination and look at $\mathrm{TiB}$ as distinct and separated from urban areas and understanding them as places in their own right, as this helps to leave behind a discussion: whether further densification or dispersion is the key to solving challenges related to sustainable development, and that they are different within urban and dispersed areas.

\section{Conflict of Interests}

The author declares no conflict of interests.

\section{References}

Andersson, E., Barthel, S., \& Ahrné, K. (2007). Measuring social-ecological dynamics behind the generation of ecosystem services. Ecological Applications, 17(5), 1267-1278. doi:10.1890/06-1116.1

Angold, P. G., Sadler, J. P., Hill, M. O., Pullin, A., Rushton, S., Austin, K., . . . Thompson, K. (2006). Biodiversity in urban habitat patches. Science of the Total Environment, 360(1), 196-204. doi:10.1016/ j.scitotenv.2005.08.035

Beninde, J., Veith, M., \& Hochkirch, A. (2015). Biodiversity in cities needs space: A meta-analysis of factors determining intra-urban biodiversity variation. Ecology Letters, 18(6), 581-592. doi:10.1111/ele.12427

Aronson, M. F., La Sorte, F. A., Nilon, C. H., Katti, M., Goddard, M. A., Lepczyk, C. A., . . Dobbs, C. (2014). A global analysis of the impacts of urbanization on bird and plant diversity reveals key anthropogenic drivers. Proceedings of the Royal Society B: Biological Sciences, 281(1780).

Beumer, C., \& Martens, P. (2014). Biodiversity in my (back)yard: Towards a framework for citizen engagement in exploring biodiversity and ecosystem services in residential gardens. Sustainability Science, 10(1), 87-100. doi:10.1007/s11625-014-0270-8

Campi, M., Bucher, F., \& Zardini, M. (2000). Annähernd perfekte Peripherie: Glattalstadt/Greater Zurich Area. Basel: Birkhäuser. 
Clauset, A., Shalizi, C. R., \& Newman, M. E. J. (2009). Power-law distributions in empirical data. SIAM Review, 51(4), 661-703. doi:10.1137/070710111

Comber, A., Brunsdon, C., \& Green, E. (2008). Using a GIS-based network analysis to determine urban greenspace accessibility for different ethnic and religious groups. Landscape and Urban Planning, 86(1), 103-114. doi:10.1016/j.landurbplan.2008.01.002

Di Giulio, M., Holderegger, R., \& Tobias, S. (2009). Effects of habitat and landscape fragmentation on humans and biodiversity in densely populated landscapes. Journal of Environmental Management, 90(10), 2959-2968. doi:10.1016/j.jenvman.2009.05.002

Dramstad, W. E., Olson, J. D., \& Forman, R. T. T. (1996). Landscape ecology principles in landscape architecture and land-use planning. Washington, DC: Island Press.

Eigenbrod, F., Bell, V. A., Davies, H. N., Heinemeyer, A., Armsworth, P. R., \& Gaston, K. J. (2011). The impact of projected increases in urbanization on ecosystem services. Proceedings of The Royal Society B: Biological Sciences, 278(1722), 3201-3208. doi:10.1098/ rspb.2010.2754

European Commission. (1997). The EU compendium of spatial planning systems and policies (Regional Development Studies 28). Luxembourg: Office for Offical Publications of the European Communities.

European Environment Agency. (2011). Landscape fragmentation in Europe. Copenhagen: EEA.

Faeth, S. H., \& Kane, T. C. (1978). Urban biogeography: City parks as islands for diptera and coleoptera. Oecologia, 32, 1217-133. doi:10.1007/BF00344697

Girvetz, E. H., Thorne, J. H., Berry, A. M., \& Jaeger, J. A. (2008). Integration of landscape fragmentation analysis into regional planning: A statewide multiscale case study from California, USA. Landscape and Urban Planning, 86(3), 205-218. doi:10.1016/ j.landurbplan.2008.02.007

Gómez-Baggethun, E., \& Barton, D. N. (2013). Classifying and valuing ecosystem services for urban planning. Ecological Economics, 86, 235-245. doi:10.1016/ j.ecolecon.2012.08.019

Hermann, M., Pentek, T., \& Otto, B. (2016). Design principles for industrie 4.0 scenarios. Proceedings of the Annual Hawaii International Conference on System Sciences, 2016-March, 3928-3937. IEEE. doi:10.1109/HICSS.2016.488

Higgs, G., Fry, R., \& Langford, M. (2012). Investigating the implications of using alternative GIS-based techniques to measure accessibility to green space. Environment and Planning B: Planning and Design, 39(2), 326-343. doi:10.1068/b37130

Huhlmann, F., \& Promski, M. (2007). Assessing contemporary cultural landscapes. Paper presented at the European Council of Landscape Architecture Schools Conference, Belgrade, Serbia.

Indovina, F. (1990). La città diffusa (The diffuse city). Venice: Istituto Universitario di Architettura.
Jaeger, J. A. G. (2002). Landschaftszerschneidungeine transdisziplinäre Studie gemäß dem Konzept der Umweltgefährdung; mit 50 Tab. Stuttgart: Ulmer.

Jaeger, J. A. G., Bertiller, R., Schwick, C., Müller, K., Steinmeier, C., Ewald, K. C., \& Ghazoul, J. (2008). Implementing landscape fragmentation as an indicator in the Swiss Monitoring System of Sustainable Development (Monet). Journal of Environmental Management, 88(4), 737-751. doi:10.1016/ j.jenvman.2007.03.043

Jaeger, J. A., Soukup, T., Madriñán, L. F., Schwick, C., \& Kienast, F. (2011). Landscape fragmentation in Europe (EEA Report No 2/2011). Copenhagen: European Environmental Agency.

Kane, K., Connors, J. P., \& Galletti, C. S. (2014). Beyond fragmentation at the fringe: A path-dependent, high-resolution analysis of urban land cover in Phoenix, Arizona. Applied Geography, 52, 123-134. doi:10.1016/j.apgeog.2014.05.002

Kasanko, M., Barredo, J. I., Lavalle, C., McCormick, N., Demicheli, L., Sagris, V., \& Brezger, A. (2006). Are European cities becoming dispersed?: A comparative analysis of 15 European urban areas. Landscape and Urban Planning, 77(1), 111-130. doi:10.1016/ j.landurbplan.2005.02.003

Le Jeannic, T., \& Vidalenc, J. (1997). Pôles urbains et périurbanisation. Le zonage en aires urbaines. INSEE première, 516, 1-2.

Lerner, A. M., \& Eakin, H. (2011). An obsolete dichotomy? Rethinking the rural-urban interface in terms of food security and production in the Global South. The Geographical Journal, 177(4), 311-320. doi:10.1111/ j.1475-4959.2010.00394.x

Lovell, S. T., \& Taylor, J. R. (2013). Supplying urban ecosystem services through multifunctional green infrastructure in the United States. Landscape Ecology, 28(8), 1447-1463. doi:10.1007/s10980-013-9912-y

Marulli, J., \& Mallarach, J. M. (2005). A GIS methodology for assessing ecological connectivity: Application to the Barcelona Metropolitan Area. Landscape and Urban Planning, 71(2/4), 243-262. doi:10.1016/ j.landurbplan.2004.03.007

Matsuoka, R. H., \& Kaplan, R. (2008). People needs in the urban landscape: Analysis of Landscape And Urban Planning contributions. Landscape and Urban Planning, 84(1), 7-19. doi:10.1016/ j.landurbplan.2007.09.009

Müller, N., \& Werner, P. (2010). Urban biodiversity and the case for implementing the convention on biological diversity in towns and cities. In N. Müller, P. Werner, \& J. G. Kelcey (Eds.), Urban biodiversity and design (pp. 3-33). Oxford: John Wiley \& Sons.

Nadin, V., \& Stead, D. (2013). Opening up the compendium: An evaluation of international comparative planning research methodologies. European Planning Studies, 21(10), 1542-1561. doi:10.1080/ 09654313.2012.722958

Neutelings, W. J. (1994). Explorations into wonderland: 
Riding the periphery of Low Countries, The Patchwork Metropolis. Architectural Design, 64, 58-63.

Park, S. (2015). Spatial assessment of landscape ecological connectivity in different urban gradient. Environmental Monitoring and Assessment, 187(7), 425. doi:10.1007/s10661-015-4645-9

Parker, S. S. (2015). Incorporating critical elements of city distinctiveness into urban biodiversity conservation. Biodiversity and Conservation, 24(3), 683-700. doi:10.1007/s10531-014-0832-1

Pickett, S., Cadenasso, M. L., Grove, J. M., Groffman, P. M., Band, L. E., Boone, C. G., . . . Wilson, M. A. (2008). Beyond urban legends: An emerging framework of urban ecology, as illustrated by the Baltimore Ecosystem Study. BioScience, 58(2), 139. doi:10.1641/B580208

Pretty, J., Peacock, J., Sellens, M., \& Griffin, M. (2005). The mental and physical health outcomes of green exercise. International Journal of Environmental Health Research, 15(5), 319-37. doi:10.1080/ 09603120500155963

Scott, A. J., Carter, C., Reed, M. R., Larkham, P., Adams, D., Morton, N., . . Coles, R. (2013). Disintegrated development at the rural-urban fringe: Re-connecting spatial planning theory and practice. Progress in Planning, 83, 1-52. doi:10.1016/j.progress.2012.09.001

Shucksmith, M. (2010). Disintegrated rural development? Neo-endogenous rural development, planning and place-shaping in diffused power contexts.
Sociologia Ruralis, 50(1), 1-14. doi:10.1111/j.14679523.2009.00497.x

Sieverts, T. (2003). Cities without cities: An interpretation of the Zwischenstadt. London: Routledge.

Sieverts, T. (2008). Where we live now. In M. Stadler (Ed.), Where we live now: An annotated reader.

Thompson, I. H. (2012). Ten tenets and six questions for landscape urbanism. Landscape Research, 37(1), 726. doi:10.1080/01426397.2011.632081

van der Hoeven, F., \& Wandl, A. (2013). Amsterwarm: Gebiedstypologie warmte-eiland Amsterdam. Retrieved from https://books.bk.tudelft.nl/index.php/ press/catalog/book/17

Van Herzele, A., \& Wiedemann, T. (2003). A monitoring tool for the provision of accessible and attractive urban green spaces. Landscape and Urban Planning, 63(2), 109-126. doi:10.1016/S0169-2046(02)00192-5

Viganò, P., Arnsperger, C., Lanza, E. C., Corte, M. B., \& Cavalieri, C. (2017). Rethinking urban form: Switzerland as a "Horizontal Metropolis". Urban Planning, 2(1), 88-99. doi:10.17645/up.v2i1.871

Wahler-Żak, B. (2017). Gartenstadt21 Ein neues Leitbild für die Stadtentwicklung in verdichteten Ballungsräumen - Vision oder Utopie? Bonn: BBSR.

Wandl, A., Nadin, V., Zonneveld, W., \& Rooij, R. (2014). Beyond urban-rural classifications: Characterising and mapping territories-in-between across Europe. Landscape and Urban Planning, 130, 50-63. doi:10.1016/j.landurbplan.2014.06.010

\section{About the Author}

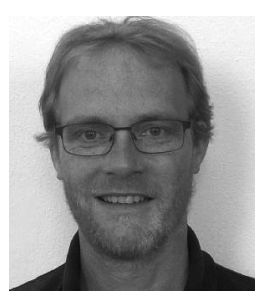

Alexander Wandl is a researcher at the Department of Urbanism at the at Faculty of Architecture and the Built Environment at TU Delft. He has a rich experience in national (BAR, NWO) and international research projects (FP7: RUFUS, NODES; ESPON: TANGO; H2020: REPAiR). His research specifically focuses on the understanding of urban form, its performance and related spatial policies through the concept of urban metabolism with a spatial focus on dispersed urban areas. His expertise lies in the integration of spatial decision and design support via geographic information systems. 